\title{
Superior performance of Ni-W-Ce mixed-metal oxide catalysts for ethanol steam reforming: Synergistic effects of W- and Ni-dopants
}

Zongyuan Liu ${ }^{a, b}$, Wenqian Xu ${ }^{a}$, Siyu Yao ${ }^{a}$, Aaron C. Johnson-Peck, Fuzhen Zhao ${ }^{a}$, Piotr Michorczyk ${ }^{d, e}$, Anna Kubacka ${ }^{d}$,Eric A. Stach ${ }^{c}$, Marcos Fernández-Garcia ${ }^{b}$, Sanjaya D. Senanayake ${ }^{a}$, José A. Rodriguez ${ }^{a, b *}$

${ }^{a}$ Chemistry Department, Brookhaven National Laboratory, Upton, NY 11973, USA

${ }^{b}$ Department of Chemistry, State University of New York (SUNY) Stony Brook, Stony Brook, NY 11794, USA

${ }^{c}$ Center for Functional Nanomaterials, Brookhaven National Laboratory, Upton, NY 11973, USA

d Instituto de Catálisis y Petroleoquímica, CSIC, Campus Cantoblanco, 28049 Madrid, Spain

e Institute of Organic Chemistry and Technology, Cracow University of Technology, Warszawska 24, 31-155 Kraków (Poland)

${ }^{*}$ Corresponding author. E-mail address: rodrigez@,bnl.gov

\section{Abstract}

The ethanol steam reforming (ESR) reaction was studied over a series of $\mathrm{Ni}-\mathrm{W}$-Ce oxide catalysts. The structures of the catalysts were characterized using in-situ techniques including X-ray diffraction, Pair Distribution Function, X-ray absorption fine structure and transmission electron microscopy; while possible surface intermediates for the ESR reaction were investigated by Diffuse Reflectance Infrared Fourier Transform Spectroscopy. In these materials, all the W and part of the $\mathrm{Ni}$ were incorporated into the $\mathrm{CeO}_{2}$ lattice, with the remaining $\mathrm{Ni}$ forming highly dispersed nano $\mathrm{NiO}(<2 \mathrm{~nm})$ outside the $\mathrm{Ni}-\mathrm{W}$-Ce oxide structure. The nano $\mathrm{NiO}$ was reduced to $\mathrm{Ni}$ under ESR conditions. The Ni-W-Ce system exhibited a much larger lattice strain than those seen for $\mathrm{Ni}-\mathrm{Ce}$ and $\mathrm{W}$-Ce. Synergistic effects between $\mathrm{Ni}$ and $\mathrm{W}$ inside ceria produced a substantial amount of defects and $\mathrm{O}$ vacancies that led to high catalytic activity, selectivity and stability (i.e. resistance to coke formation) during ethanol steam reforming.

Keywords: Steam reforming of ethanol; Lattice strain; Oxygen vacancies; Nickel; Ceria; Tungsten; DRIFTS; XRD; XAFS 


\section{Introduction}

Most fuel cell types require hydrogen for their operation and many technologies are under investigation looking for efficient and non-expensive routes for hydrogen generation. Hydrogen production through the steam reforming of ethanol $\left(\mathrm{CH}_{3} \mathrm{CH}_{2} \mathrm{OH}+3 \mathrm{H}_{2} \mathrm{O} \rightarrow 2 \mathrm{CO}_{2}+6 \mathrm{H}_{2}\right)$ is receiving a tremendous amount of attention because the ethanol is readily available from energy-renewable sources such as bio-mass [1-3]. On metal/oxide catalysts, the ethanol steam reforming (ESR) process occurs by a complex mechanism involving multiple reactions $[2,4,5]$. It has been postulated that this mechanism requires bifunctional catalysts $[3,6,7]$, with the metal component contributing to the $\mathrm{C}-\mathrm{C}$ and $\mathrm{C}-\mathrm{H}$ bond scissions and the oxide support promoting the dehydrogenation (or dehydration) reaction as well as the dissociation of $\mathrm{H}_{2} \mathrm{O}$. Then, the adsorbed C-related species $\left(\mathrm{CH}_{x}, \mathrm{C}, \mathrm{CO}\right)$ couple with the adsorbed $\mathrm{OH}$ groups or lattice oxygen from the oxide support at the metal-support interface, generating an intermediate which further reforms and dissociates into $\mathrm{CO}_{2}$ and hydrogen. Deactivation of the metal/oxide catalysts occurs as a consequence of coke formation and metal particle sintering.

The nature of the metal and support directly influence catalytic activity and stability during the ESR process. Expensive noble metals such as Rh, Pt and Ru exhibit good catalytic activity and a relatively good stability, while a metal with a low cost like Ni deactivates due to coke formation $[2,7]$. In principle, coke formation on a metal could be prevented by perturbing the electronic properties of the metal through interactions with the oxide support $[6,7]$, by controlling metal particle size $[7,8]$ and by enhancing the capacity for oxygen storage and mobility within the oxide support [9]. Mixed-metal oxides are attractive as potential catalysts for the ESR process [2, $6,7,9]$. The introduction of dopants into the lattice of the oxide support could enhance metal- 
support interactions and thereby impact the electronic properties of the metal and oxide to produce surface sites which are very active for the cleavage of the $\mathrm{C}-\mathrm{C}, \mathrm{C}-\mathrm{H}$ and $\mathrm{O}-\mathrm{H}$ bonds present in the reactants $[6,7]$. At a structural level, the dopants could impose strain into the lattice of the oxide host [9], inducing in this way the formation of defects that could affect the anchoring of the supported metal on the surface and alter the redox properties of the system leading to a higher mobility of oxygen.

In this study, we investigated the structural and chemical properties of a series of catalysts which contain small nanoparticles of $\mathrm{Ni}$ dispersed on $\mathrm{Ni}_{x} \mathrm{~W}_{\mathrm{y}} \mathrm{Ce}_{1-\mathrm{x}-\mathrm{y}} \mathrm{O}_{2}$ solid solutions prepared by reverse micro-emulsion methods. As can be seen in Scheme 1, the most stable oxides of $\mathrm{Ce}, \mathrm{Ni}$ and $W$ adopt very different crystal structures and formal oxidation states $(4+, 2+$ and $6+$, respectively). Furthermore, Ce cations prefer a coordination number of 8 , while $\mathrm{Ni}$ and $\mathrm{W}$ cations adopt a coordination number of 6 . Thus, doping of ceria with $\mathrm{Ni}$ or $\mathrm{W}$ could induce substantial electronic and structural perturbations in the host oxide. Our studies point to synergistic effects when $\mathrm{Ni}$ and $\mathrm{W}$ are confined inside ceria; effects which make the performance of $\mathrm{Ni} / \mathrm{Ni}_{x} \mathrm{~W}_{y} \mathrm{Ce}_{1-\mathrm{x}-\mathrm{y}} \mathrm{O}_{2}$ catalysts as good or better than that of catalysts containing expensive noble metals such as $\mathrm{Rh}$ and $\mathrm{Pt}[7,10-12]$. This synergistic effect between $\mathrm{Ni}$ and $\mathrm{W}$ can be important in several areas of chemistry and material sciences in which ceria is widely used $[13,14]$. In the Ni-W-Ce ternary system, the addition of tungsten as a stable phase inside the ceria lattice raises several questions: what is the role of tungsten and nickel? How is the bimetal-oxides interaction compared with a single dopant? Does the oxygen mobility of ceria even more improved as an oxygen storage substrate? To answer these questions, we will first examine the structural and electronic properties of as-prepared $\mathrm{Ni}_{x} \mathrm{~W}_{\mathrm{y}} \mathrm{Ce}_{1-\mathrm{x}-\mathrm{y}} \mathrm{O}_{2}$ by means of $\mathrm{X}-$ ray Diffraction (XRD), Pair Distribution Function (PDF), X-ray Absorption Fine Structure (XAFS) and Scanning Transmission Electron Microscopy (STEM). Then, the behavior of the $\mathrm{Ni}_{x} \mathrm{~W}_{y} \mathrm{Ce}_{1-x-y} \mathrm{O}_{2}$ 
catalysts under ethanol steam reforming conditions will be investigated by operando XRD, XAFS and Diffuse Reflectance Infrared Fourier Transform Spectroscopy (DRIFTS) studies to follow phase evolutions and surface intermediates during the reaction.

\section{Experimental}

\subsection{Sample preparation}

References $[15,16]$ describe in detail the procedure used to prepare the samples. The Ni-W-Ce catalysts were prepared by the use of reverse micro-emulsions with solutions containing nheptane (organic solvent), Triton-X-100 (surfactant) and n-hexanol (co-surfactant) in amounts similar to those reported previously $[15,16]$. The required amounts of ceria nitrate (Aldrich), nickel nitrate (Aldrich) and ammonium tungsten oxide (Aldrich) were dissolved in distilled water and dispersed within already mentioned organic components to form the reverse microemulsion. Simultaneously, another micro-emulsion of similar characteristics was prepared containing dissolved in its aqueous phase, the required amount of tetramethyl ammonium hydroxide (TMAH). After $1 \mathrm{~h}$ of stirring the two micro-emulsions, the TMAH-containing solution was added to the metal-containing one, and it was left for a period of $24 \mathrm{~h}$ with continuous stirring in order to complete the precipitation reaction. The resulting solid was then separated by centrifugation and decantation, rinsed with methanol, and dried overnight at $100{ }^{\circ} \mathrm{C}$. The resulting powder was calcined at $500{ }^{\circ} \mathrm{C}$ for $2 \mathrm{~h}$ in air. Chemical compositions were analyzed by ICP-AES and correspond to the ones mentioned in the sample names within a maximum error of \pm 2 at \%. No significant amount of impurities was detected by ICP-AES and the other techniques used to characterize the catalysts. 


\subsection{X-ray diffraction and Pair distribution function (PDF) analysis}

In situ time-resolved X-ray diffraction (TR-XRD) experiments in conjunction with mass spectrometry for product analysis were performed at beamline X7B $(\lambda=0.3196 \AA)$ of the National Synchrotron Light Source (NSLS) at Brookhaven National Laboratory (BNL). The samples ( 2.5 $\mathrm{mg}$ ) were loaded into a silica capillary $(0.9 \mathrm{~mm} I D, 1.0 \mathrm{~mm} \mathrm{OD})$ mounted on a flow system [17] to test the ethanol steam reforming activity. The generation of the saturated ethanol vapor or water vapor was achieved by passing He through a bubbler filled with pure ethanol or deionized water. The gas flow rate used in this study, $10 \mathrm{cc} / \mathrm{min}$, was sufficiently low to guarantee that the gases passing through the bubblers reached a vapor saturated state. At $25{ }^{\circ} \mathrm{C}$, the saturated vapor pressure was 0.08 bar for ethanol and 0.03 bar for water. A target $\mathrm{EtOH} / \mathrm{H}_{2} \mathrm{O}$ molar ratio of $1 / 6$ was achieved by mixing the two vapor gases with an adjustable flow rate for each [18]. The weight-hourly-space-velocity (WHSV), defined as the ratio between the inlet feed (water + ethanol) mass flow rate and the mass of the catalyst, was $10 \mathrm{~h}^{-1}$. A resistance heating coil was placed underneath the capillary, and the temperature was monitored with a type K thermocouple inserted into the capillary next to the sample [17]. The heating process followed a stepped temperature program from room temperature to $450^{\circ} \mathrm{C}\left(50^{\circ} \mathrm{C}\right.$ increment, $\left.10^{\circ} \mathrm{C} / \mathrm{min}\right)$. A Perkin-Elmer Amorphous silicon detector was used to collect two-dimensional transmission diffraction data, and the powder diffraction rings were integrated using the FIT2D program [19] to obtain the XRD profiles. The lattice parameters and phase fractions were analyzed by the Rietveld method with the aid of the GSAS code $[20,21]$. The instrument parameters were derived from fitting of a $\mathrm{LaB}_{6}$ standard sample. Errors in the calculated oxide lattice parameters by XRD are in the order of $\pm 0.001 \AA$.

PDF analysis is a total elastic scattering technique that takes into account features from both Bragg diffractions and diffuse scattering, so that non-crystalline phases can also be probed. A 
PDF profile describes the distribution of all pairs of atoms within a sample as a function of interatomic distances. The PDF data collection in this study was done with the same instruments used for collecting XRD data. A $0.5 \mathrm{~mm}$ ID Kapton tube was used as the sample container. Data processing was performed with PDFgetX3 [22]. Errors in the calculated metal-oxygen and metalmetal distances by PDF are in the order of $\pm 0.03 \AA$.

\subsection{X-ray absorption fine-structure (XAFS)}

X-ray absorption spectra of the $\mathrm{W} \mathrm{L}_{1,3}$-edges and $\mathrm{Ni}$ K-edge were recorded at beamline $\mathrm{X} 19 \mathrm{~A}$ of NSLS. The sample powders were uniformly spread with a brush over adhesive Kapton polyamide tapes. The X-ray absorption near edge spectra (XANES) or extended X-ray absorption fine structure (EXAFS) spectra were taken repetitiously in the fluorescence-yield mode with a passivated implanted planar silicon (PIPS) detector. The XANES and EXAFS data were then analyzed using the Athena and Artemis programs [23]. Errors in the calculated metal-oxygen and metal-metal distances by EXAFS are in the order of $\pm 0.02 \AA$.

\subsection{Diffuse Reflectance Infrared Fourier Transform Spectroscopy (DRIFTS)}

DRIFTS data for the $\mathrm{Ni}_{\mathrm{x}} \mathrm{W}_{\mathrm{y}} \mathrm{Ce}_{1-\mathrm{x}-\mathrm{y}} \mathrm{O}_{2}$ samples under ESR conditions were collected on a Bruker Equinox 55 FTIR spectrometer equipped with a modified Harrick Praying Mantis DRIFT cell. The gas flow parameters and heating ramp were kept similar to the ones used in the XRD experiments. Details of the instrument can be found elsewhere [24].

\subsection{HRTEM and STEM}

TEM images were obtained using a JEOL JEM 2100 instrument operating with an acceleration voltage of $200 \mathrm{kV}$. Sample powders were dispersed as a suspension in deionized water and sonicated for 60 s. After being well dispersed, a droplet of suspension was deposited on HoleyCarbon coated $\mathrm{Cu}$ grids and allowed to dry before imaging. Electron energy loss spectroscopy 
(EELS) was acquired on a Hitachi $2700 \mathrm{C}$ operated at $200 \mathrm{kV}$ using a convergence semi-angle of 23 mrad while the collection angle on the EELS spectrometer was 26 mrad.

\section{Results and Discussion}

\subsection{Structural and electronic properties of the Ni-W-Ce catalysts}

\subsubsection{XRD and TEM}

In previous studies, we examined the properties of $\mathrm{Ni}_{\mathrm{x}} \mathrm{Ce}_{1-\mathrm{x}} \mathrm{O}_{2}$ and $\mathrm{W}_{\mathrm{y}} \mathrm{Ce}_{1-\mathrm{y}} \mathrm{O}_{2}$ materials $[7,12,14,18]$. The concentration of the dopant that could be introduced inside the ceria lattice forming a solid solution was limited: $10-15 \%$ in the case of $\mathrm{Ni}$ and $20-25 \%$ in the case of $\mathrm{W} . \mathrm{Ni}^{2+}$ replaced $\mathrm{Ce}^{4+}$ cations and induced the formation of $\mathrm{O}$ vacancies and $\mathrm{Ce}^{3+}$ sites $[7,14]$. On the other hand, $\mathrm{W}^{6+}$ cations were present in $\mathrm{W}_{\mathrm{y}} \mathrm{Ce}_{1-\mathrm{y}} \mathrm{O}_{2}$ after creating an $\mathrm{O}$ vacancy and replacing two $\mathrm{Ce}^{3+}$ centers in the original $\mathrm{CeO}_{2}$ structure [12]. In principle, two $\mathrm{Ce}^{4+}$ cations could be replaced by a $\left(\mathrm{Ni}^{2+}, \mathrm{W}^{6+}\right)$ pair inside the ceria lattice. In this work, three $\mathrm{Ni}_{x} \mathrm{~W}_{\mathrm{y}} \mathrm{Ce}_{1-\mathrm{x}-\mathrm{y}} \mathrm{O}_{2}$ samples with $\mathrm{W}$ contents from 0 to $20 \%$ were studied: $\mathrm{Ni}_{0.2} \mathrm{Ce}_{0.8} \mathrm{O}_{2}, \mathrm{Ni}_{0.2} \mathrm{~W}_{0.1} \mathrm{Ce}_{0.7} \mathrm{O}_{2}$ and $\mathrm{Ni}_{0.2} \mathrm{~W}_{0.2} \mathrm{Ce}_{0.6} \mathrm{O}_{2}$, in which W and Ni were doped into ceria simultaneously by using reverse micro-emulsion. The top panel in Fig. 1 shows XRD profiles of the as-prepared samples. All the diffraction patterns for $\mathrm{Ni}_{\mathrm{x}} \mathrm{W}_{\mathrm{y}} \mathrm{Ce}_{1}$ ${ }_{x-y} \mathrm{O}_{2}$ samples showed a major contribution from a ceria fluorite-type structure and no peaks attributed to tungsten-related species could be observed in any case, which indicates that there is no crystalline tungsten-related phases in these samples. For the Ni-containing samples, three weak peaks attributed to a $\mathrm{NiO}$ phase (marked by red arrows in Fig. 1) were observed and their intensities increased along with the increase of $\mathrm{W}$ content. For comparison, Fig. 1 also shows the XRD pattern of a Ni-impregnated sample ( $20 \%$ Ni physically deposited on a W-Ce support, noted as $\left.\mathrm{Ni}_{0.2} / \mathrm{W}_{0.2} \mathrm{Ce}_{0.8} \mathrm{O}_{2}\right)$, in which the $20 \% \mathrm{Ni}$ was all present in the crystalline $\mathrm{NiO}$ phase. Though 
having the same loading of $\mathrm{Ni}$, the three $\mathrm{Ni}_{x} \mathrm{~W}_{y} \mathrm{Ce}_{1-\mathrm{x}-\mathrm{y}} \mathrm{O}_{2}$ samples prepared by reverse microemulsion show much weaker $\mathrm{NiO}$ peaks than the $\mathrm{Ni}_{0.2} / \mathrm{W}_{0.2} \mathrm{Ce}_{0.8} \mathrm{O}_{2}$ sample generated by impregnation, suggesting that part of the $\mathrm{Ni}$ in the $\mathrm{Ni}_{x} \mathrm{~W}_{y} \mathrm{Ce}_{1-\mathrm{x}-\mathrm{y}} \mathrm{O}_{2}$ samples was incorporated into the ceria lattice. Rietveld refinement provided molar fractions of $7 \%, 9 \%$ and $12 \%$ for the $\mathrm{NiO}$ phase in $\mathrm{Ni}_{0.2} \mathrm{Ce}_{0.8} \mathrm{O}_{2}, \mathrm{Ni}_{0.2} \mathrm{~W}_{0.1} \mathrm{Ce}_{0.7} \mathrm{O}_{2}$ and $\mathrm{Ni}_{0.2} \mathrm{~W}_{0.2} \mathrm{Ce}_{0.6} \mathrm{O}_{2}$, respectively. The amount of the $\mathrm{Ni}$ embedded in the ceria can be calculated by subtracting the amount of the NiO phase from the total $\mathrm{Ni}$ loading, giving $13 \%, 11 \%$ and $8 \%$ for $\mathrm{Ni}_{0.2} \mathrm{Ce}_{0.8} \mathrm{O}_{2}, \mathrm{Ni}_{0.2} \mathrm{~W}_{0.1} \mathrm{Ce}_{0.7} \mathrm{O}_{2}$ and $\mathrm{Ni}_{0.2} \mathrm{~W}_{0.2} \mathrm{Ce}_{0.6} \mathrm{O}_{2}$, respectively (table 1 ). In contrast to $\mathrm{W}, \mathrm{Ni}$ was not fully incorporated into the ceria lattice. Moreover, the results show that the Ni solubility limit was reduced by the addition of $\mathrm{W}$. The more $\mathrm{W}$ was embedded into the ceria structure, the less $\mathrm{Ni}$ was able to accept in its lattice the oxide host.

The bottom panel in Figure 1 shows lattice parameters determined through Rietveld refinement of the XRD data. In general, the introduction of $\mathrm{W}^{6+}$ or $\mathrm{Ni}^{2+}$ in the ceria produces an expansion in the lattice constant $[7,12,25]$. This expansion has also been observed in calculations with Density Functional Theory (DFT) and is a consequence of differences in the sizes of $\mathrm{Ni}, \mathrm{W}$ and $\mathrm{Ce}$ plus the introduction of oxygen vacancies $\left(\mathrm{Ce}^{3+}\right)$ in the ceria lattice $[7,12,25]$. The $\mathrm{Ni}_{0.2} \mathrm{~W}_{0.1} \mathrm{Ce}_{0.7} \mathrm{O}_{2}$ and $\mathrm{Ni}_{0.2} \mathrm{~W}_{0.2} \mathrm{Ce}_{0.6} \mathrm{O}_{2}$ systems have lattice parameters which are larger than that of $\mathrm{CeO}_{2}$ but smaller than the one seen in $\mathrm{Ni}_{0.2} \mathrm{Ce}_{0.8} \mathrm{O}_{2}$ [7]. The direction and magnitude of the variations in the ceria lattice constant upon doping is difficult to predict [14, 25-28]. If the dopant cation has the same charge of the original cation $\left(\mathrm{Zr}^{4+}\right.$ or $\mathrm{U}^{4+}$ versus $\mathrm{Ce}^{4+}$, for example), one can compare directly the relative sizes of the two cations $[9,28-30]$. On the other hand, if the dopant cation has a different charge from the original cation, the situation is much more complex and not only a difference in the relative size of the cations can produce variations in the lattice parameter of ceria $[9,14,25-27]$. A difference in the charge of the cations usually is 
accompanied by the formation of oxygen vacancies and $\mathrm{Ce}^{3+}$ centers plus variations in local structure. The substantial difference in sizes between $\mathrm{Ce}^{3+}$ and $\mathrm{Ce}^{4+}$ can overcome or compensate the difference in size between the dopant cations and the $\mathrm{Ce}^{4+}[9,14,25-27]$. Thus, in practice, it is very difficult to predict what the doping with $\mathrm{W}^{6+}$ or $\mathrm{Ni}^{2+}$ will do to the lattice parameters of ceria.

Images of scanning transmission electron microscopy (STEM) for the as-synthesized $\mathrm{Ni}_{0.2} \mathrm{~W}_{0.1} \mathrm{Ce}_{0.7} \mathrm{O}_{2}$ sample are presented in Fig. 2a-b. The ceria nanoparticles exhibited a size of 4-6 $\mathrm{nm}$ which matched well with the particle sizes estimated from XRD (table 1 ). Fig. $2 \mathrm{~b}-2 \mathrm{f}$ shows a STEM image of the sample and the corresponding electron energy loss spectroscopy (EELS) mapping of $\mathrm{Ce}, \mathrm{Ni}$ and $\mathrm{W}$. As Fig. $2 \mathrm{~d}$ shows, all the particles presented in Fig. $2 \mathrm{c}$ were ceria nanoparticles, no big crystalline particles related to Ni or W were seen. Ni exhibited two types of structures (Fig. 2e): Small NiO clusters $(<2 \mathrm{~nm}$ cluster size) on top of the bulk ceria and mono dispersed cations inside the ceria lattice. In contrast, W was evenly distributed over all the imaged ceria particles, Fig. $2 f$, indicating that the $\mathrm{W}$ was either well mixed into the ceria lattice or formed an amorphous $\mathrm{WO}_{\mathrm{x}}$ phase uniformly dispersed covering the surface of all ceria particles. The latter possibility was rejected because disordered shells were not observed on the ceria particles. A corresponding EELS line profile taken across the diameter of a typical ceria nanoparticle provided further evidence of W embedded in the ceria lattice (See SI figure 1).

\subsubsection{XAFS and PDF}

$W L_{1}$-edge XANES data (Fig. 3) provides information about the oxidation states and local symmetry of the $\mathrm{W}$ dopant, obtained from the position of the X-ray absorption edge and the pre-edge peak intensity, respectively. As mentioned above, two $\mathrm{Ce}^{4+}$ cations could be replaced 
by a $\left(\mathrm{Ni}^{2+}, \mathrm{W}^{6+}\right)$ pair inside the ceria lattice. Furthermore, the doping of ceria with $\mathrm{W}^{6+}$ could involve the formation of an $\mathrm{O}$ vacancy and the removal of two $\mathrm{Ce}^{3+}$ cations [12]. As shown in Fig. 3 , the oxidation state of the as-prepared sample remained the same as a reference $\mathrm{WO}_{3}$ sample

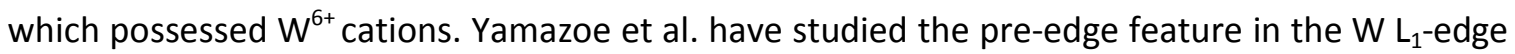
XANES of various $W$ species with different symmetries $\left(O_{h}\right.$ symmetry, distorted $O_{h}$ symmetry, $T_{d}$ symmetry) [31]. They reported that regular $\mathrm{WO}_{6}$ units with $\mathrm{O}_{\mathrm{h}}$ symmetry as in $\mathrm{Cr}_{2} \mathrm{WO}_{6}$ had a trivial pre-edge peak and its intensity increased along when the $W$ symmetry shifted from $O_{h}$ to $T_{d}$. In this study, we used $\mathrm{Na}_{2} \mathrm{WO}_{4}$ as a reference for a local structure with a typical $\mathrm{T}_{d}$ symmetry characterized by a large pre-edge peak. In comparison, $\mathrm{WO}_{3}$ which had been proved to have distorted $\mathrm{O}_{\mathrm{h}}$ geometry showed a moderate pre-edge peak [31]. Our as-prepared $\mathrm{Ni}-\mathrm{W}-\mathrm{Ce}$ samples all shared similar line-shapes with $\mathrm{WO}_{3}$ indicating a distorted $\mathrm{O}_{\mathrm{h}}$ symmetry for $\mathrm{W}$ in these samples, and the distortion might be larger than in the case of $\mathrm{WO}_{3}$ if one considers the slightly larger pre-edge feature for the as-prepared samples. It is worth noting that the symmetry of the $\mathrm{W}$ units was not affected by the addition of Ni. Ni K-edge XANES revealed a +2 oxidation state for $\mathrm{Ni}$ in all of the as-prepared samples (see SI figure 2).

$\mathrm{W} \mathrm{L}_{3}$-edge EXAFS was performed to investigate the coordination numbers and bonding distance between $\mathrm{W}$ and its neighboring atoms. Fourier transformed R-space EXAFS data, Fig. 4a, showed a dominant $\mathrm{W}-\mathrm{O}$ first shell peak. Theoretical fitting of the $\mathrm{W}-\mathrm{O}$ first shell suggested the coordination number was 6-7, in agreement with $\mathrm{W}$ in a distorted octahedral coordination environment (see SI table 1). A second shell at around $3.86 \AA$ could be attributed to W-W bonds, and it is only observed in reference $\mathrm{WO}_{3}$ but not in any of the $\mathrm{W}$-doped samples. This is a strong indication of a W-Ce solid solution since incorporation of isolated W cations into the ceria lattice would result in no observation of $\mathrm{W}-\mathrm{W}$ bonding features. A relatively similar phenomenon was also found in the Ni EXAFS (Fig. 4b). The first shell at $2.06 \AA$ could be assigned to Ni-O bonding 
(fitting results see $\mathrm{SI}$ table 2). For $\mathrm{Ni}_{0.2} \mathrm{~W}_{0.1} \mathrm{Ce}_{0.7} \mathrm{O}_{2}$, this first shell peak was broad and the mean square disorder factor was three times larger than the one for $\mathrm{Ni}_{0.2} / \mathrm{W}_{0.2} \mathrm{Ce}_{0.8} \mathrm{O}_{2}$, which indicates a more distorted first shell for $\mathrm{Ni}$ in $\mathrm{Ni}_{0.2} \mathrm{~W}_{0.1} \mathrm{Ce}_{0.7} \mathrm{O}_{2}$ than in $\mathrm{Ni}_{0.2} / \mathrm{W}_{0.2} \mathrm{Ce}_{0.8} \mathrm{O}_{2}$. According to the XRD results above, $\mathrm{Ni}_{0.2} \mathrm{~W}_{0.1} \mathrm{Ce}_{0.7} \mathrm{O}_{2}$ has $9 \% \mathrm{NiO}$ phase and $11 \%$ embedded $\mathrm{Ni}$ while $\mathrm{Ni}_{0.2} / \mathrm{W}_{0.2} \mathrm{Ce}_{0.8} \mathrm{O}_{2}$ had $20 \% \mathrm{NiO}$ with no $\mathrm{Ni}$ embedded to the ceria. It is clear that the broadening feature observed for $\mathrm{Ni}_{0.2} \mathrm{~W}_{0.1} \mathrm{Ce}_{0.7} \mathrm{O}_{2}$ is owed to the incorporated $\mathrm{Ni}$, whose bonding distances to $\mathrm{O}$ is expected to show larger variance than in a crystalline NiO phase. The second shell at around 2.95Å was attributed to the closest $\mathrm{Ni}-\mathrm{Ni}$ distance. This shell is strong in the $\mathrm{NiO}$ reference and in $\mathrm{Ni}_{0.2} / \mathrm{W}_{0.2} \mathrm{Ce}_{0.8} \mathrm{O}_{2}$ but shows a dramatic decrease in intensity for $\mathrm{Ni}_{0.2} \mathrm{~W}_{0.2} \mathrm{Ce}_{0.7} \mathrm{O}_{2}$ and even more in $\mathrm{Ni}_{0.2} \mathrm{~W}_{0.1} \mathrm{Ce}_{0.7} \mathrm{O}_{2}$. Fitting of this shell gave a $\mathrm{Ni}-\mathrm{Ni}$ coordination number decreasing from 12 of the bulk $\mathrm{NiO}$ to an average of about 7 in $\mathrm{Ni}_{0.2} \mathrm{~W}_{0.1} \mathrm{Ce}_{0.7} \mathrm{O}_{2}$. This substantial reduction in the average coordination number of nickel may be a consequence of having very small particles of $\mathrm{NiO}$ well dispersed on the ceria [32, 33].

Further structural information came from the PDF data. As shown in Fig. 5a, the addition of W gave rise to the emergence of a W-O peak at $1.76 \AA$ (EXAFS fitting showed to be $\sim 1.78 \AA$ ) and a small decrease of the Ce-O peak intensity at $2.32 \AA$ due to the reduced $\mathrm{Ce}-\mathrm{O}$ pairs and concomitant presence of $\mathrm{O}$ defects. When there was $\mathrm{Ni}$ doping (Fig. 5b), the $\mathrm{Ni}-\mathrm{O}$ and $\mathrm{Ni}-\mathrm{Ni}$ correlations showed up at $2.05 \AA$ and $2.95 \AA$, respectively, matched well with the EXAFS fitting of these two bonding distances. The progressive decrease of the Ni-Ni peak intensity confirmed a trend similar to that observed in the Ni K-edge EXAFS.

Thus, on the basis of our XRD, TEM, XAFS and PDF studies, we conclude that W was uniformly embedded into the ceria lattice with a distorted W-O octahedral local structure. Ni was partially 
incorporated into the ceria lattice and the remaining $\mathrm{Ni}$ formed small $\mathrm{NiO}$ clusters over the $\mathrm{Ni}$ W-Ce solid solution.

\subsection{Ethanol steam reforming performance of $\mathrm{Ni}-\mathrm{W}-\mathrm{Ce}$}

\subsubsection{Activity, selectivity and stability during the ESR reaction}

In a previous study, we showed that $\mathrm{Ni}_{x} \mathrm{Ce}_{1-\mathrm{x}} \mathrm{O}_{2}$ solid solutions have a higher activity and a better stability for the ESR reaction than expensive $\mathrm{Rh} / \mathrm{CeO}_{2}$ catalysts [7]. Here, we will focus on the performance of $\mathrm{Ni}_{x} \mathrm{~W}_{y} \mathrm{Ce}_{1-x-y} \mathrm{O}_{2}$ using $\mathrm{Ni}_{x} \mathrm{Ce}_{1-x} \mathrm{O}_{2}$ as a benchmark. As shown in Fig. 6, all the samples investigated started to produce a small amount of $\mathrm{H}_{2}$ when the temperature was raised to around $350^{\circ} \mathrm{C}\left(300^{\circ} \mathrm{C}\right.$ for $\left.\mathrm{Ni}_{0.2} \mathrm{Ce}_{0.8} \mathrm{O}_{2}\right)$, but the activity was not stable over time. Substantial $\mathrm{H}_{2}$ production was observed as the temperature reached $450^{\circ} \mathrm{C}$. Among the $\mathrm{Ni}_{x} \mathrm{~W}_{\mathrm{y}} \mathrm{Ce}_{1-\mathrm{x}-\mathrm{y}} \mathrm{O}_{2}$ samples in the lower panel of Figure $6, \mathrm{Ni}_{0.2} \mathrm{~W}_{0.1} \mathrm{Ce}_{0.7} \mathrm{O}_{2}$ showed the highest and the most stable catalytic activity compared to the conventional nickel-impregnated sample $\left(\mathrm{Ni}_{0.2} / \mathrm{CeO}_{2}\right)$. At $450 \mathrm{C}$, the ethanol conversion on $\mathrm{Ni}_{0.2} \mathrm{~W}_{0.1} \mathrm{Ce}_{0.7} \mathrm{O}_{2}$ was $100 \%$. Note that, from 400 to $450^{\circ} \mathrm{C}$, the reforming activity of $\mathrm{Ni}_{0.2} \mathrm{~W}_{0.2} \mathrm{Ce}_{0.6} \mathrm{O}_{2}$ remained stable while the activity on $\mathrm{Ni}_{0.2} \mathrm{Ce}_{0.8} \mathrm{O}_{2}$ decreased slightly. From these activity data, one can find that the W-promoted catalysts showed higher $\mathrm{H}_{2}$ production than the non W-doped samples. In addition, the solid solution $\mathrm{Ni}$ samples (lower panel) were generally more stable during the steam reforming reactions than the conventional Ni-impregnated samples (upper panel).

Showing the best catalytic performance, $\mathrm{Ni}_{0.2} \mathrm{~W}_{0.1} \mathrm{Ce}_{0.7} \mathrm{O}_{2}$ was also examined for the co-products at the steam reforming reaction conditions (Fig. 7). As the temperature increased, the amount of the produced $\mathrm{H}_{2}$ and $\mathrm{CO}_{2}$ tracked each other and stepwise increased as expected for the reforming process. The signal for $\mathrm{CH}_{3}(\mathrm{~m} / \mathrm{z}=15)$ in the mass spectrum continuously decreased 
and became negligible at $450^{\circ} \mathrm{C}$. This signal was mainly a contribution of the reactant ethanol $\mathrm{CH}_{3}$ fragment and the product of methane $\left(\mathrm{CH}_{4}\right)$ if any. The stepwise decrease of the $\mathrm{CH}_{3}$ reflected the consumption of ethanol as the temperature increased, while a value close to zero at $450{ }^{\circ} \mathrm{C}$ indicated a close to complete conversion of ethanol and no observable production of methane. Nickel particles on supported oxides are well known catalysts for the formation of methane as well as the deactivation by coke deposition $[2,6,34]$. But clearly, the methanation reaction was not a competing reaction path for $\mathrm{Ni}_{0.2} \mathrm{~W}_{0.1} \mathrm{Ce}_{0.7} \mathrm{O}_{2}$ at $450^{\circ} \mathrm{C}$. We also tested the catalytic activity for a long period (24hrs) and the $\mathrm{H}_{2}$ production remained stable without any sign of deactivation (see SI Fig 3). A small production of CO was observed based on the signal of $\mathrm{m} / \mathrm{z}=28$, which was mainly contributed by both $\mathrm{CO}$ and the cracking of $\mathrm{CO}_{2}$. Calculated $\mathrm{CO} / \mathrm{CO}_{2}$ ratio in the gas fragments at $450{ }^{\circ} \mathrm{C}$ was 1:6. No other significant by-products were detected by mass spectrometry. At $450{ }^{\circ} \mathrm{C}$, the $\mathrm{Ni}_{0.2} \mathrm{~W}_{0.1} \mathrm{Ce}_{0.7} \mathrm{O}_{2}$ catalyst exhibited a performance that was better in terms of activity and stability than that found under similar conditions for an expensive $\mathrm{Rh} / \mathrm{CeO}_{2}$ catalyst [7]. However, the small amount of $\mathrm{CO}$ produced indicates that the $\mathrm{Ni}_{0.2} \mathrm{~W}_{0.1} \mathrm{Ce}_{0.7} \mathrm{O}_{2}$ catalyst does not have a water-gas shift activity as high as that found on $\mathrm{Rh}-$ based catalyst $[2,11]$.

\subsubsection{DRIFTS studies and surface intermediates for the ESR reaction}

The in situ DRIFTS studies of Figure 8 shows the surface intermediates detected for the ESR reaction on $\mathrm{CeO}_{2}, \mathrm{~W}_{0.1} \mathrm{Ce}_{0.9} \mathrm{O}_{2}$ and $\mathrm{Ni}_{0.2} \mathrm{~W}_{0.1} \mathrm{Ce}_{0.7} \mathrm{O}_{2}$ as a function of temperature. The most important features appear near $2348 \mathrm{~cm}^{-1}$ as a consequence of the formation of $\mathrm{CO}_{2}$ from the reforming of ethanol. These features are absent in the case of pure $\mathrm{CeO}_{2}$ and strong for $\mathrm{Ni}_{0.2} \mathrm{~W}_{0.1} \mathrm{Ce}_{0.7} \mathrm{O}_{2}$. For pure $\mathrm{CeO}_{2}$ at $25{ }^{\circ} \mathrm{C}$, the dissociative adsorption of ethanol produced ethoxy $\left(\mathrm{CH}_{3} \mathrm{CH}_{2} \mathrm{O}\right)$ with 
features at 1110 and $1050 \mathrm{~cm}^{-1}$ for monodentate-v(C-O) and bidentate-v(C-O) coordinations, respectively [35, 36]. From 150 to $200{ }^{\circ} \mathrm{C}$, three peaks coresponding to acetate $\left(\mathrm{CH}_{3} \mathrm{COO}-\right)$ started to be resolved at 1550, 1437 and $1343 \mathrm{~cm}^{-1}$ which are identified as $\mathrm{v}_{\mathrm{s}}(\mathrm{COO}), \mathrm{v}_{\mathrm{as}}(\mathrm{COO})$ and $\delta_{s}\left(\mathrm{CH}_{3}\right)$, respectively $[2,37,38]$. In addition, the intensities of the ethoxy CO bands at 1110 and $1050 \mathrm{~cm}^{-1}$ decreased and disapeared at $300{ }^{\circ} \mathrm{C}$. However, a further increase of the temperature from 300 to $450{ }^{\circ} \mathrm{C}$ did not produce a significant change in the IR features or the production of $\mathrm{CO}_{2}$. On the $\mathrm{W}_{0.1} \mathrm{Ce}_{0.9} \mathrm{O}_{2}$ and $\mathrm{Ni}_{0.2} \mathrm{~W}_{0.1} \mathrm{Ce}_{0.7} \mathrm{O}_{2}$ samples, a transition from acetate to carbonate species $\left(v_{\text {as }}\right.$ OCO $1467 \mathrm{~cm}^{-1}$ and $v_{s}$ OCO $1394 \mathrm{~cm}^{-1}$ ) [2, 39] occurred above $400{ }^{\circ} \mathrm{C}$ with simultaneous formation of $\mathrm{CO}_{2}$. The acetate $\rightarrow$ carbonate transition is associated with the high activity observed for $\mathrm{Ni}_{0.2} \mathrm{~W}_{0.1} \mathrm{Ce}_{0.7} \mathrm{O}_{2}$ in Figures 6 and 7. Furthermore, at $450{ }^{\circ} \mathrm{C}$, the catalyst has reached a stable structural configuration, as will be explained below using results of XRD and XAFS.

\subsubsection{In-situ XRD and structural changes}

In situ XRD experiments were performed to gain insight into the structural changes of the catalysts during the steam reforming process. Fig. 9a displays a time sequence of XRD profiles for $\mathrm{Ni}_{0.2} \mathrm{~W}_{0.1} \mathrm{Ce}_{0.7} \mathrm{O}_{2}$ taken during the steam reforming of ethanol. No W-related species were seen through the entire study, indicating that the W-Ce solid solution is stable under the reaction conditions. On the other hand, the $\mathrm{NiO}$ clusters identified by the three weak peaks at $7.6^{\circ}, 8.8^{\circ}$ and $12.4^{\circ}$ remained unchanged till $400^{\circ} \mathrm{C}$, at which temperature a clear transition from $\mathrm{NiO}$ to metallic Ni was observed. Quantification of the phase transitions as a function of time was plotted in the upper panel of Figure 9b. At first, the catalysts started to be active for $\mathrm{H}_{2}$ production at $350^{\circ} \mathrm{C}$ when metallic Ni was substantially formed. However, one can observe that the appearance of metallic Ni was not accompanied by a similar decrease in the mole fraction of 
the NiO phase, which implies that some of the $\mathrm{Ni}$ cations inside ceria were reduced and segregated to the surface prior to the reduction of $\mathrm{NiO}$ clusters outside ceria crystallites [14]. Then, the NiO phase began to be reduced from $400^{\circ} \mathrm{C}$ and eventually vanished at $450^{\circ} \mathrm{C}$ while $\mathrm{H}_{2}$ production reached its maximum as a consequence of a massively formed metallic Ni phase. Moreover, Rietveld refinement also provided information about the ceria lattice expansion of $\mathrm{Ni}_{0.2} \mathrm{~W}_{0.1} \mathrm{Ce}_{0.7} \mathrm{O}_{2}$ with respect to the reference sample as shown in the lower panel of Fig. $9 \mathrm{~b}$. Upon thermal treatment, one can expect a stepwise lattice expansion of ceria lattice coming along with the stepwise heating. However, between 200 and $300{ }^{\circ} \mathrm{C}$, a sharp jump of the lattice constant could be related to the non-thermal expansion resulting from the reduction of ceria from $\mathrm{Ce}^{4+}$ to $\mathrm{Ce}^{3+}$ since $\mathrm{Ce}^{3+}$ has a larger atomic radii than $\mathrm{Ce}^{4+}[27,40]$. The formation of $\mathrm{Ce}^{3+}$ was regarded as evidence of the creation of oxygen vacancies in the ceria lattice. It is known that ceria will undergo reduction prior to the reduction of $\mathrm{NiO}$ during the steam reforming $[7,18$, 40], but the substantial reduction in $\mathrm{Ni}_{0.2} \mathrm{~W}_{0.1} \mathrm{Ce}_{0.7} \mathrm{O}_{2}$ is unique among all the Ni-related samples investigated here. The magnitude of the lattice expansion was influenced by the coexistence of $\mathrm{W}$ and $\mathrm{Ni}$ as dopants: $\mathrm{Ni}_{0.2} \mathrm{~W}_{0.1} \mathrm{Ce}_{0.7} \mathrm{O}_{2}$ had a lattice expansion 1.5 times larger than that of $\mathrm{Ni}_{0.2} \mathrm{Ce}_{0.8} \mathrm{O}_{2}$ and 2 times larger than the one for $\mathrm{Ni}$-impregnated ceria $\left(\mathrm{Ni}_{0.2} / \mathrm{CeO}_{2}\right)$, which implies that the number of oxygen vacancies in the $\mathrm{Ni}_{x} \mathrm{~W}_{y} \mathrm{Ce}_{1-x-y} \mathrm{O}_{2}$ ternary system was also much larger.

Figure 10a shows the lattice strain of fresh samples derived from XRD profiles by Rietveld refinement $[20,41,42]$. For $\mathrm{W}$-Ce samples without $\mathrm{Ni}$ doping, a trend of increasing lattice strain along with increasing $\mathrm{W}$ content is observed. However, $\mathrm{Ni}_{0.2} \mathrm{~W}_{0.1} \mathrm{Ce}_{0.7} \mathrm{O}_{2}$ has a much larger strain than $\mathrm{Ni}_{0.2} \mathrm{Ce}_{0.8} \mathrm{O}_{2}$ or $\mathrm{W}_{0.1} \mathrm{Ce}_{0.9} \mathrm{O}_{2}$. Thus, there is a synergy between $\mathrm{Ni}$ and $\mathrm{W}$ for the production of strain in the oxide lattice. It is well known that lattice strain is a product of the presence of imperfections and dislocations in the oxide lattice $[9,26,30,43,44]$. These defects can act as nucleation centers and enhance the dispersion of reduced $\mathrm{Ni}$ on the surface while aiding with 
the dissociation of water and ethanol $[45,46,47,48]$. Time-sequential analysis of the $\mathrm{Ni}_{0.2} \mathrm{~W}_{0.1} \mathrm{Ce}_{0.7} \mathrm{O}_{2}$ XRD profiles collected during the reforming reaction revealed that its lattice strain varied during the reaction process (figure 10b) and always remained at a very high value. Thus, the concentration of defects and imperfections in this system was always bigger than those on $\mathrm{Ni}_{0.2} \mathrm{Ce}_{0.8} \mathrm{O}_{2}, \mathrm{~W}_{0.1} \mathrm{Ce}_{0.9} \mathrm{O}_{2}, \mathrm{Ni} / \mathrm{CeO}_{2}$ or $\mathrm{CeO}_{2}$ giving the ternary oxide unique catalytic properties. From the viewpoint of selectivity, this may favor the formation of a high concentration of $\mathrm{OH}$ groups on the surface $[6,13,46]$ facilitating the reaction of $\mathrm{CH}_{\mathrm{x}}$ species with $\mathrm{OH}$ to yield $\mathrm{CO}_{2}$ and $\mathrm{H}_{2}$ instead of methane and coke.

\subsubsection{In situ XAFS}

Similar experiments were carried out with in situ time-resolved XAFS. Notably, since the kapton tube is limited for a maximum temperature of $380^{\circ} \mathrm{C}$, a silica tube with $0.1 \mathrm{~mm}$ wall thickness was used. Several spectra at each temperature were collected and merged to improve the signal-to-noise ratio. $\mathrm{Ce} \mathrm{L}_{3}$-edge XANES spectra for $\mathrm{Ni}_{0.2} \mathrm{~W}_{0.1} \mathrm{Ce}_{0.7} \mathrm{O}_{2}$ under steam reforming conditions are displayed in Fig. 11. One can observe that, in pure $\mathrm{CeO}_{2}$, the $\mathrm{Ce}_{3}$-edge exhibited two clear peaks for $\mathrm{Ce}^{4+}$, which could be easily distinguished from the single sharp white line of $\mathrm{Ce}^{3+}$ at lower photon energy. By comparing with standards for $\mathrm{Ce}^{3+}$ and $\mathrm{Ce}^{4+}$, we were able to identify that a significant amount of $\mathrm{Ce}^{4+}$ in $\mathrm{Ni}_{0.2} \mathrm{~W}_{0.1} \mathrm{Ce}_{0.7} \mathrm{O}_{2}$ was reduced to $\mathrm{Ce}^{3+}$ from $250^{\circ} \mathrm{C}$ to $350^{\circ} \mathrm{C}$ and remained almost unchanged up to $450^{\circ} \mathrm{C}$, in good consistency with the in situ XRD results for ceria lattice expansion with temperature. In addition, the peak intensity at the $\mathrm{Ce}^{3+}$ positions of the sample was apparently more intense than the reference pure $\mathrm{CeO}_{2}$ at $450^{\circ} \mathrm{C}$ (blue dash line) under steam reforming conditions, indicating the improved ceria reducibility due to the combined effects of $\mathrm{Ni}$ and $\mathrm{W}$ as dopants. 
Ni K-edge XANES spectra for $\mathrm{Ni}_{0.2} \mathrm{~W}_{0.1} \mathrm{Ce}_{0.7} \mathrm{O}_{2}$ were also collected under the same conditions. As the temperature increased, the $\mathrm{NiO}$ reduction was relatively small from room temperature to $350^{\circ} \mathrm{C}$ and a substantial reduction took place from $350^{\circ} \mathrm{C}$ to $450^{\circ} \mathrm{C}$. Eventually, some of the $\mathrm{Ni}$ still remained oxidized at $450^{\circ} \mathrm{C}$ inside the lattice of ceria. XRD data at $450{ }^{\circ} \mathrm{C}$ showed the $\mathrm{NiO}$ phase had been completely reduced to metallic $\mathrm{Ni}$, but provided little direct information about the embedded $\mathrm{Ni}$. The Ni K-edge EXAFS data however are rich in details associated with the $\mathrm{NiO} \rightarrow \mathrm{Ni}$ transition (Fig. 12). The intensity of the first two shells around 2.0 and $3.0 \AA$ at $25^{\circ} \mathrm{C}$, which corresponds to $\mathrm{Ni}-\mathrm{O}$ and $\mathrm{Ni}-\mathrm{Ni}$ distances in $\mathrm{NiO}$ respectively, gradually decreased at elevated temperature combined with an increase of the Ni-Ni peak in the metallic $\mathrm{Ni}$ phase around $2.6 \AA$. At $450^{\circ} \mathrm{C}$, the metallic $\mathrm{Ni}-\mathrm{Ni}$ peak was broad and of much lower intensity compared to the one for the Ni foil, which indicates that the newly formed metallic Ni was still present as small clusters (i.e. Ni atoms with a low coordination number) instead of forming large $\mathrm{Ni}$ particles $[33,49]$, in agreement with the broad peak feature see for $\mathrm{Ni}$ metal in the corresponding XRD patterns. The extremely small particle size of $\mathrm{Ni}$ (or even atomic $\mathrm{Ni}$ ) gave it a strong adherence to the ceria support, which guaranteed the sufficient supply of $\mathrm{OH}$ from the surrounding ceria and also prevented its sintering. Furthermore, small Ni particles in close contact with ceria are electronically perturbed, as shown by experiments of photoemission $[7,45]$ and DFT calculations [34], and do not exhibit the typical methanation activity of bulk nickel [8, $14,34,50]$. Big Ni particles will decompose ethanol into $\mathrm{CH}_{\mathrm{x}}$ groups and $\mathrm{C}$ atoms $[8,50]$. As a consequence of this, carbon will be accumulated on the catalysts surface and finally will encapsulate the active sites. This does not occur for the small Ni particles dispersed on Ni-W-Ce.

In situ studies for the $\mathrm{W} \mathrm{L}_{1}$-edge of $\mathrm{Ni}_{0.2} \mathrm{~W}_{0.1} \mathrm{Ce}_{0.7} \mathrm{O}_{2}$ were also performed at the elevated temperature and no changes were found with respect to the line-shape of the fresh sample seen in Fig. 3. Combined with the XRD data that showed no occurrence of any W-related 
crystalline phase, this confirms that the $\mathrm{W}^{+6}$ cations remained inside the ceria lattice through the entire reaction. Thus, from the in situ XAFS studies, we can conclude that the active phase of the catalyst involves small $\mathrm{Ni}$ nanoparticles dispersed on a $\mathrm{Ni}-\mathrm{W}$-Ce solid solution in which the $\mathrm{Ni}$ and $\mathrm{W}$ are fully oxidized and part of the $\mathrm{Ce}^{4+}$ has been transformed into $\mathrm{Ce}^{3+}$. In previous studies, we have found that this catalyst configuration is active for the water-gas shift reaction [12] and we envision that the system could also be useful for hydrogen/deuterium exchange, olefin hydrogenation, and methane/steam reforming.

\section{Summary and Conclusions}

We have studied the steam reforming of ethanol over a series of $\mathrm{Ni}-\mathrm{W}$-Ce catalysts. A combination of XRD, PDF, TEM and XAFS revealed that $\mathrm{W}$ and part of the $\mathrm{Ni}$ formed a solid solution with ceria in the $\mathrm{Ni}_{x} \mathrm{~W}_{\mathrm{y}} \mathrm{Ce}_{1-\mathrm{x}-\mathrm{y}} \mathrm{O}_{2}$ catalysts while the remaining $\mathrm{Ni}$ was well dispersed on the surface as small $\mathrm{NiO}$ clusters. The $\mathrm{Ni}-\mathrm{W}$-Ce systems exhibited a much larger lattice strain than those seen for $\mathrm{Ni}-\mathrm{Ce}$ and $\mathrm{W}-\mathrm{Ce}$. Synergistic effects between $\mathrm{Ni}$ and $\mathrm{W}$ inside ceria produced a substantial amount of defects and $\mathrm{O}$ vacancies that led to a high catalytic activity, selectivity and stability for the ethanol steam reforming reaction. At $450{ }^{\circ} \mathrm{C}$, a $\mathrm{Ni}_{0.2} \mathrm{~W}_{0.1} \mathrm{Ce}_{0.7} \mathrm{O}_{2}$ catalyst exhibited a performance that was better in terms of activity and stability than that found under similar conditions for an expensive $\mathrm{Rh} / \mathrm{CeO}_{2}$ catalyst.

The reaction pathway leading to the production of $\mathrm{CO}_{2}$ and $\mathrm{H}_{2}$ included the formation of ethoxy, acetate and carbonate surface species while the active components of the catalysts most likely were metallic $\mathrm{Ni}$ and $\mathrm{Ce}^{3+} . \mathrm{W}$ - and $\mathrm{Ni}$-doping promoted the formation of $\mathrm{Ce}^{3+}$ sites, helping the partial dissociation of water. The formation of a high concentration of $\mathrm{OH}$ groups on the catalyst surface facilitated the transformation of $\mathrm{CH}_{\mathrm{x}}$ species into $\mathrm{CO}_{2}$ and $\mathrm{H}_{2}$ instead of methane and 
coke. Furthermore, the presence of defects and imperfections in the $\mathrm{Ni}_{x} \mathrm{~W}_{\mathrm{y}} \mathrm{Ce}_{1-\mathrm{x}-\mathrm{y}} \mathrm{O}_{2}$ substrate favored the dispersion of the supported $\mathrm{Ni}$ and strong metal-support interactions $[7,34,35]$ that probably modified the chemical reactivity of the admetal.

\section{Acknowledgement}

The research carried out at National Synchrotron Light Source, Brookhaven National Laboratory, was supported by the U.S. Department of Energy, Office of Science, Office of Basic Energy Sciences (DE-AC02-98CH10886 contract). STEEM-EELS data were obtained at the Center for Functional Nanomaterials, supported by the U.S. Department of Energy, Office of Basic Energy Sciences under contract No DE-AC02-98CH10886. The financial support from the National Natural Science Foundation of China (Grant 21303272) and China Scholarship Council (File No.

201208420304) is gratefully acknowledged. Anna Kubacka thanks Spanish MINECO for a "Ramón y Cajal" postdoctoral fellowship.

\section{References}

[1] G.W. Huber, S. Iborra, A. Corma, Chem. Rev. 106 (2006) 4044-4098.

[2] L.V. Mattos, G. Jacobs, B.H. Davis, F.b.B. Noronha, Chem. Rev. 112 (2012) 4094-4123.

[3] M. Dominguez, E. Taboada, H. Idriss, E. Molins, J. Llorca, J. Mater. Chem. 20 (2010) 48754883.

[4] P.R. de la Piscina, N. Homs, Chem. Soc. Rev. 37 (2008) 2459-2467.

[5] S.M. de Lima, A.M. da Silva, L.O. da Costa, U.M. Graham, G. Jacobs, B.H. Davis, L.V. Mattos, F.B. Noronha, J. Catal. 268 (2009) 268-281.

[6] S.D. Senanayake, J. Evans, S. Agnoli, L. Barrio, T.-L. Chen, J. Hrbek, J.A. Rodriguez, Top. Catal. 54 (2011) 34-41.

[7] G. Zhou, L. Barrio, S. Agnoli, S.D. Senanayake, J. Evans, A. Kubacka, M. Estrella, J.C. Hanson, A. Martínez-Arias, M. Fernández-García, J.A. Rodriguez, Angew. Chem. 122 (2010) 9874-9878.

[8] J.R. Rostrup-Nielsen, J. Sehested, J.K. Nørskov, Advances In Catalysis, Academic Press.

47(2002) 65-139. 
[9] A. Gupta, U. Waghmare, M. Hegde, Chem. Mater. 22 (2010) 5184-5198.

[10] J. Breen, R. Burch, H. Coleman, Appl. Catal. B 39 (2002) 65-74.

[11] A.K. Wahab, T. Odedairo, J. Labis, M. Hedhili, A. Delavar, H. Idriss, Appl. Petrochem. Res. 3 (2013) 83-89.

[12] F. Zhao, Z. Liu, W. Xu, S. Yao, A. Kubacka, A.C. Johnston-Peck, S.D. Senanayake, A.-Q. Zhang, E.A. Stach, M. Fernández-García, J.A. Rodriguez, J. Phys. Chem. C 118 (2014) 2528-2538.

[13] M. Fernandez-Garcia, A. Martinez-Arias, J. Hanson, J. Rodriguez, Chem. Rev. 104 (2004) 4063-4104.

[14] L. Barrio, A. Kubacka, G. Zhou, M. Estrella, A. Martínez-Arias, J.C. Hanson, M. FernándezGarcía, J.A. Rodriguez, J. Phys. Chem. C 114 (2010) 12689-12697.

[15] A. Martínez-Arias, M. Fernández-García, V. Ballesteros, L.N. Salamanca, J.C. Conesa, C. Otero, J. Soria, Langmuir 15 (1999) 4796-4802.

[16] D. Gamarra, C. Belver, M. Fernández-García, A. Martínez-Arias, J. Am. Chem. Soc. 129 (2007) 12064-12065.

[17] A.I. Frenkel, Q. Wang, N. Marinkovic, J.G. Chen, L. Barrio, R. Si, A.L.p. Cámara, A.M. Estrella, J.A. Rodriguez, J.C. Hanson, J. Phys. Chem. C 115 (2011) 17884-17890.

[18] W. Xu, Z. Liu, A.C. Johnston-Peck, S.D. Senanayake, G. Zhou, D. Stacchiola, E.A. Stach, J.A. Rodriguez, ACS Catalysis 3 (2013) 975-984.

[19] A. Hammersley, S. Svensson, M. Hanfland, A. Fitch, D. Hausermann, High Pressure Res. 14 (1996) 235-248.

[20] A.C. Larson, R.B. Von Dreele, General Structure Analysis System. LANSCE, MS-H805, Los Alamos, New Mexico (1994).

[21] B.H. Toby, J. Appl. Crystallogr. 34 (2001) 210-213.

[22] P. Juhas, T. Davis, C.L. Farrow, S.J.L. Billinge, J. Appl. Crystallogr. 46 (2013) 560-566.

[23] B. Ravel, M. Newville, J. Synchrotron. Radiat. 12 (2005) 537-541.

[24] N.S. Marinkovic, Q. Wang, A.I. Frenkel, J. Synchrotron. Radiat. 18 (2011) 447-455.

[25] X. Wang, J.A. Rodriguez, J.C. Hanson, D. Gamarra, A. Martínez-Arias, M. Fernández-García, J. Phys. Chem. B 109 (2005) 19595-19603.

[26] J.A. Rodriguez, X. Wang, J.C. Hanson, G. Liu, A. Iglesias-Juez, M. Fernández-García, J. Chem. Phys. 119 (2003) 5659-5669.

[27] X. Wang, J.C. Hanson, G. Liu, J.A. Rodriguez, A. Iglesias-Juez, M. Fernández-García, J. Chem. Phys. 121 (2004) 5434-5444.

[28] J.A. Rodriguez, J.C. Hanson, J.-Y. Kim, G. Liu, A. Iglesias-Juez, M. Fernández-García, J. Phys. Chem. B 107 (2003) 3535-3543.

[29] Y. Al-Salik, I. Al-Shankiti, H. Idriss, J. Electron Spectrosc. 194 (2014) 66-73.

[30] R. Grau-Crespo, N.H. de Leeuw, S. Hamad, U.V. Waghmare, Proc. R. Soc. A. 467 (2011) 19251938.

[31] S. Yamazoe, Y. Hitomi, T. Shishido, T. Tanaka, J. Phys. Chem. C 112 (2008) 6869-6879.

[32] A.I. Frenkel, C.W. Hills, R.G. Nuzzo, J. Phys. Chem. B 105 (2001) 12689-12703.

[33] C.N. Ávila-Neto, D. Zanchet, C.E. Hori, R.U. Ribeiro, J.M.C. Bueno, J. Catal. 307 (2013) 222-

237.

[34] J. Carrasco, L. Barrio, P. Liu, J.A. Rodriguez, M.V. Ganduglia-Pirovano, J. Phys. Chem. C 117 (2013) 8241-8250.

[35] H. Song, U.S. Ozkan, J. Catal. 261 (2009) 66-74.

[36] A. Yee, S.J. Morrison, H. Idriss, J. Catal. 191 (2000) 30-45.

[37] S.M. de Lima, A.M. Silva, U.M. Graham, G. Jacobs, B.H. Davis, L.V. Mattos, F.B. Noronha, Appl. Catal. A 352 (2009) 95-113.

[38] L. Mattos, F. Noronha, J. Catal. 233 (2005) 453-463. 
[39] G.N. Vayssilov, M. Mihaylov, P.S. Petkov, K.I. Hadjiivanov, K.M. Neyman, J. Phys. Chem. C 115 (2011) 23435-23454.

[40] W. Xu, R. Si, S.D. Senanayake, J. Llorca, H. Idriss, D. Stacchiola, J.C. Hanson, J.A. Rodriguez, J. Catal. 291 (2012) 117-126.

[41] R. Jenkins, R. Snyder, Introduction to X-ray powder diffractometry, John Wiley \& Sons, 2012. [42] A. Serquis, Y.T. Zhu, E.J. Peterson, J.Y. Coulter, D.E. Peterson, F.M. Mueller, Appl. Phys. Lett. 79 (2001) 4399-4401.

[43] A. Kossoy, A.I. Frenkel, Q. Wang, E. Wachtel, I. Lubomirsky, Adv. Mater. 22 (2010) 16591662.

[44] D.A. Andersson, S.I. Simak, N.V. Skorodumova, I.A. Abrikosov, B. Johansson, Appl. Phys. Lett. 90 (2007) 031909.

[45] Y. Zhou, J. Zhou, J. Phys. Chem. C, 116 (2012) 9544-9549.

[46] D.R. Mullins, P.M. Albrecht, T.-L. Chen, F.C. Calaza, M.D. Biegalski, H.M. Christen, S.H.

Overbury, J. Phys. Chem. C, 116 (2012) 19419-19428.

[47] D.R. Mullins, S. Senanayake, T.-L. Chen, J. Phys. Chem. C, 114 (2010) 17112-17119.

[48] H. Idriss, Platinum Metals Rev. 48 (2004) 105-115.

[49] V.M. Gonzalez-Delacruz, R. Pereñiguez, F. Ternero, J.P. Holgado, A. Caballero, ACS Catalysis 1 (2011) 82-88.

[50] H.S. Bengaard, J.K. Nørskov, J. Sehested, B. Clausen, L. Nielsen, A. Molenbroek, J. RostrupNielsen, J. Catal. 209 (2002) 365-384. 
Table 1. NiO phase fraction, ceria lattice parameters and particle sizes extracted from XRD.

\begin{tabular}{lccc}
\hline \multicolumn{1}{c}{ Catalysts } & $\begin{array}{c}\text { NiO phase } \\
\text { fraction (\%) }\end{array}$ & $\begin{array}{c}\text { Ceria Lattice } \\
\text { parameters (Å) }\end{array}$ & $\begin{array}{c}\text { Ceria particle } \\
\text { sizes (nm) }\end{array}$ \\
\hline $\mathrm{Ni}_{0.2} \mathrm{Ce}_{0.8} \mathbf{O}_{2}$ & 7 & 5.410 & 5.0 \\
\hline $\mathrm{Ni}_{0.2} \mathbf{W}_{0.1} \mathrm{Ce}_{0.7} \mathbf{O}_{2}$ & 9 & 5.405 & 4.5 \\
\hline $\mathrm{Ni}_{0.2} \mathbf{W}_{0.2} \mathrm{Ce}_{0.6} \mathbf{O}_{2}$ & 12 & 5.404 & 4.3 \\
\hline
\end{tabular}

\section{Figure Captions}

Scheme 1: Crystal structures of $\mathrm{CeO}_{2}, \mathrm{NiO}$ and $\mathrm{WO}_{3}$

Figure 1. XRD patterns of the as-prepared samples (solid line) and reference samples (dash line).

Figure 2. Selected STEM images $(a, b)$ and EELS mapping (c,d,e,f) of the as-prepared $\mathrm{Ni}_{0.2} \mathrm{~W}_{0.1} \mathrm{Ce}_{0.7} \mathrm{O}_{2}$. The area inside the square displayed in Fig $2 \mathrm{~b}$ was used for the EELS mapping. The element map was colored to identify and indicate the distribution of corresponding elements: Ce (blue), Ni (green), W (red).

Figure 3. $W L_{1}$-edge XANES spectra of as-prepared samples (solid line) as well as the reference sample (dash line).

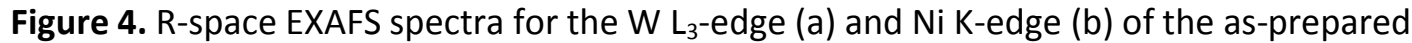
catalysts. 
Figure 5. PDF spectra of the fresh samples: a) W-O system, b) Ni-W-O system.

Figure 6. $\mathrm{H}_{2}$ production plots for ethanol steam reforming over a) $\mathrm{Ni}$-impregnated sample, b) $\mathrm{Ni}_{\mathrm{x}} \mathrm{W}_{\mathrm{y}} \mathrm{Ce}_{1-\mathrm{x}-\mathrm{y}} \mathrm{O}_{2}$ solid solution samples. The samples were held at each isothermal condition for at least half an hour. Catalyst mass $=\sim 2.5 \mathrm{mg}$, a vapor mixture of water and ethanol (molar ratio $6: 1$ ) carried by He gas (total flow $=10 \mathrm{ccm} / \mathrm{min}$ ), WHSV $=10 \mathrm{~h}^{-1}$.

Figure 7. Mass spectroscopic data of the reaction products $\left(\mathrm{H}_{2}, \mathrm{CO}_{2}, \mathrm{CO}\right.$ and $\left.\mathrm{CH}_{4}\right)$ during the ethanol steam reforming over a $\mathrm{Ni}_{0.2} \mathrm{~W}_{0.1} \mathrm{Ce}_{0.7} \mathrm{O}_{2}$ catalyst. At $450 \mathrm{C}$, the ethanol conversion on this catalyst was $100 \%$. Catalyst mass $=\sim 2.5 \mathrm{mg}$, a vapor mixture of water and ethanol (molar ratio $6: 1)$ carried by a flow $(10 \mathrm{ccm} / \mathrm{min})$ of He gas, WHSV $=10 \mathrm{~h}^{-1}$.

Figure 8. DRIFTS spectra of $\mathrm{CeO}_{2}, \mathrm{~W}_{0.1} \mathrm{Ce}_{0.9} \mathrm{O}_{2}$ and $\mathrm{Ni}_{0.2} \mathrm{~W}_{0.1} \mathrm{Ce}_{0.7} \mathrm{O}_{2}$ at elevating temperature under steam reforming conditions

Figure 9. a) TR-XRD pattern for $\mathrm{Ni}_{0.2} \mathrm{~W}_{0.1} \mathrm{Ce}_{0.7} \mathrm{O}_{2}$ collected during the ESR process, the $\mathrm{NiO}$ and fcc-Ni are marked. b) Sequential Rietveld refinement of the Ni phase fraction (upper panel) and the ceria lattice parameter (lower panel).

Figure 10. a) Rietveld Refinement of the ceria lattice strain for a series of fresh sample with and without $\mathrm{Ni}$ loading. b) Sequential Rietveld refinement of the variation of ceria lattice strain under ethanol steam reforming conditions, $\mathrm{Ni}_{0.2} \mathrm{Ce}_{0.8} \mathrm{O}_{2}$ and $\mathrm{Ni}_{0.2} / \mathrm{CeO}_{2}$ were chosen as a comparison to the $\mathrm{Ni}_{0.2} \mathrm{~W}_{0.1} \mathrm{Ce}_{0.7} \mathrm{O}_{2}$ catalyst.

Figure 11. $\mathrm{Ce} \mathrm{L}_{3}$-edge XANES spectra collected over $\mathrm{Ni}_{0.2} \mathrm{~W}_{0.1} \mathrm{Ce}_{0.7} \mathrm{O}_{2}$ during ethanol steam reforming reaction at elevated temperatures (solid line). Dash line: reference of $\mathrm{Ce}^{3+}$ $\left(\mathrm{Ce}\left(\mathrm{NO}_{3}\right)_{3} \cdot 6 \mathrm{H}_{2} \mathrm{O}\right)$ at $25^{\circ} \mathrm{C}$, reference of $\mathrm{Ce}^{4+}\left(\mathrm{CeO}_{2}\right)$ at $25^{\circ} \mathrm{C}$ and $450^{\circ} \mathrm{C}$ under steam.

Figure 12. In situ $\mathrm{Ni} \mathrm{K}$-edge XAFS spectra of $\mathrm{Ni}_{0.2} \mathrm{~W}_{0.1} \mathrm{Ce}_{0.7} \mathrm{O}_{2}$ under ethanol steam reforming conditions at different temperatures. a) XANES part, b) Fourier transformed R-space of EXAFS part. 


\section{TOC graphic}
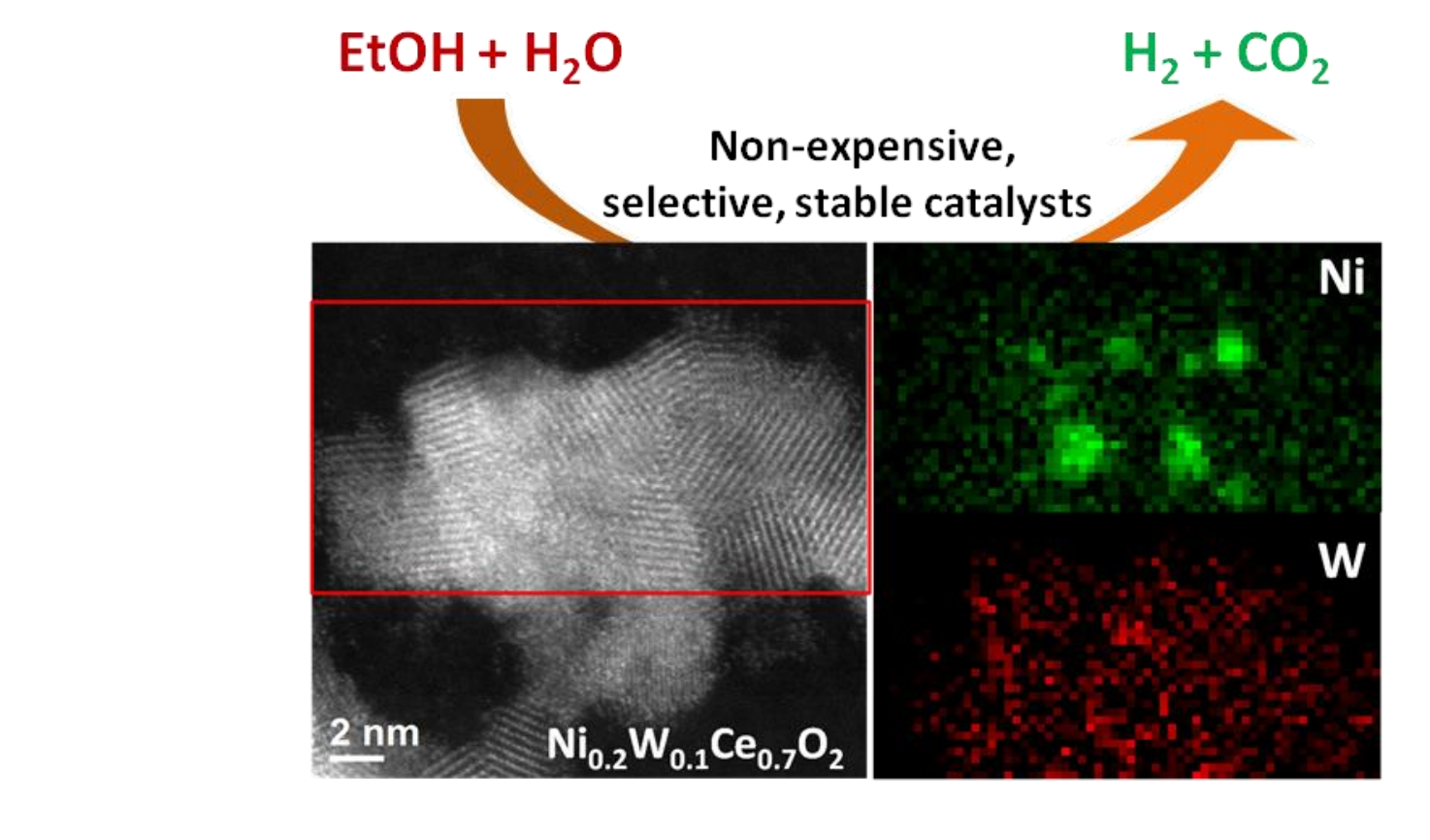

roxomente

.

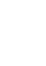

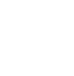

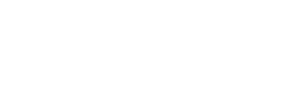



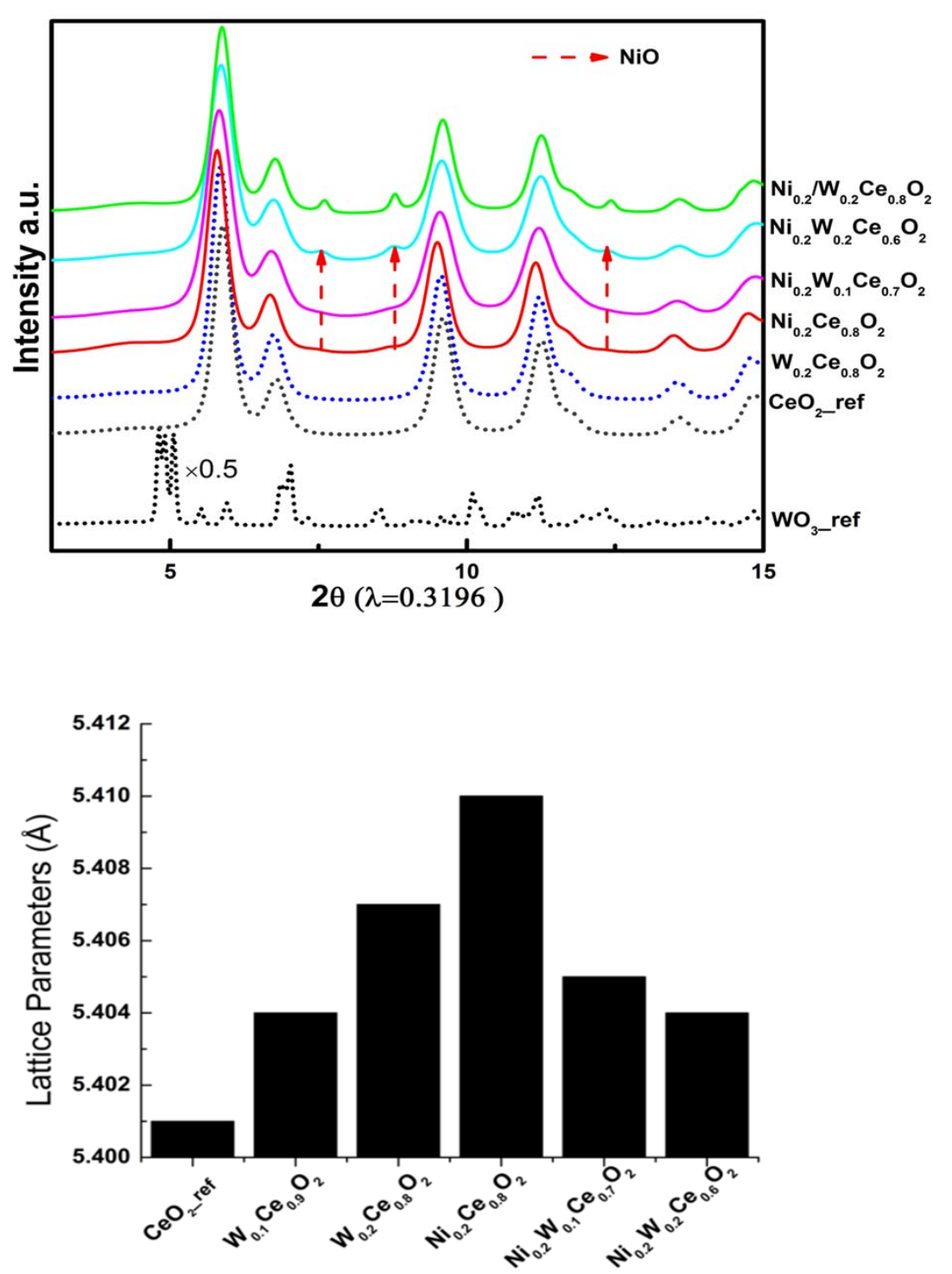

Fig 1 


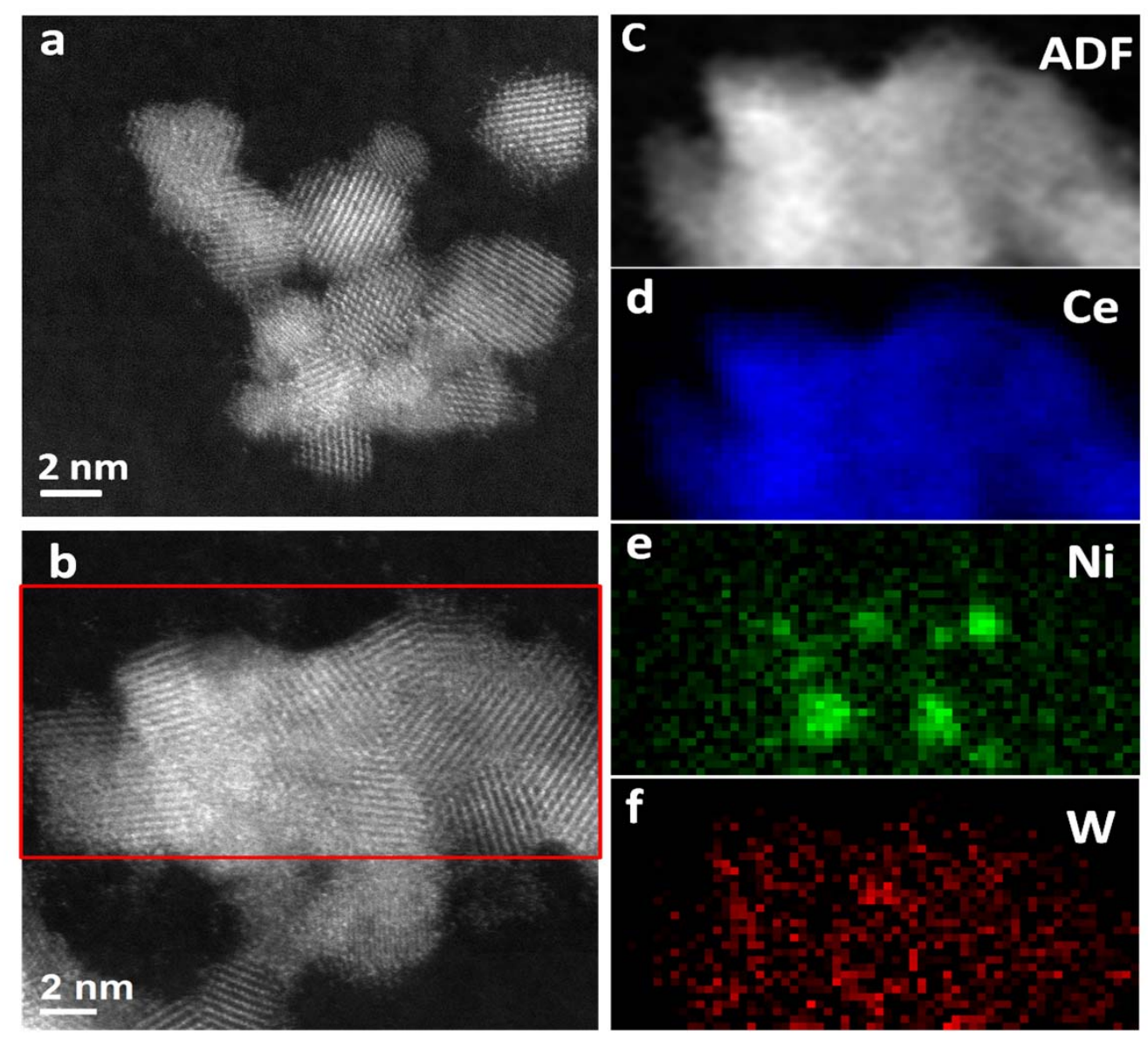

Fig 2 


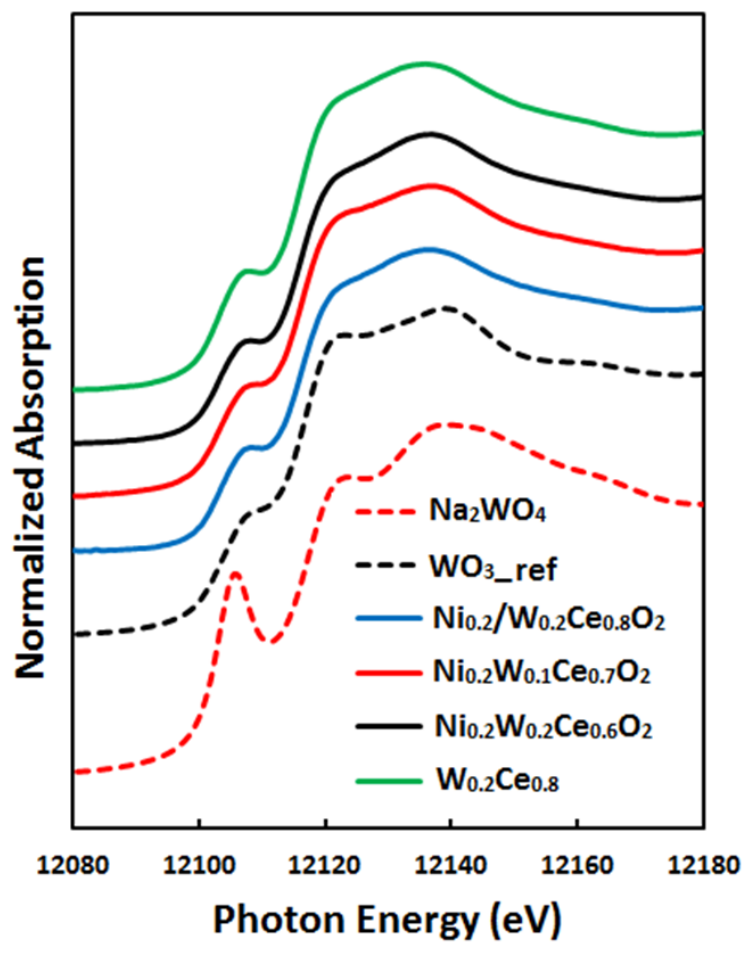

Fig 3 

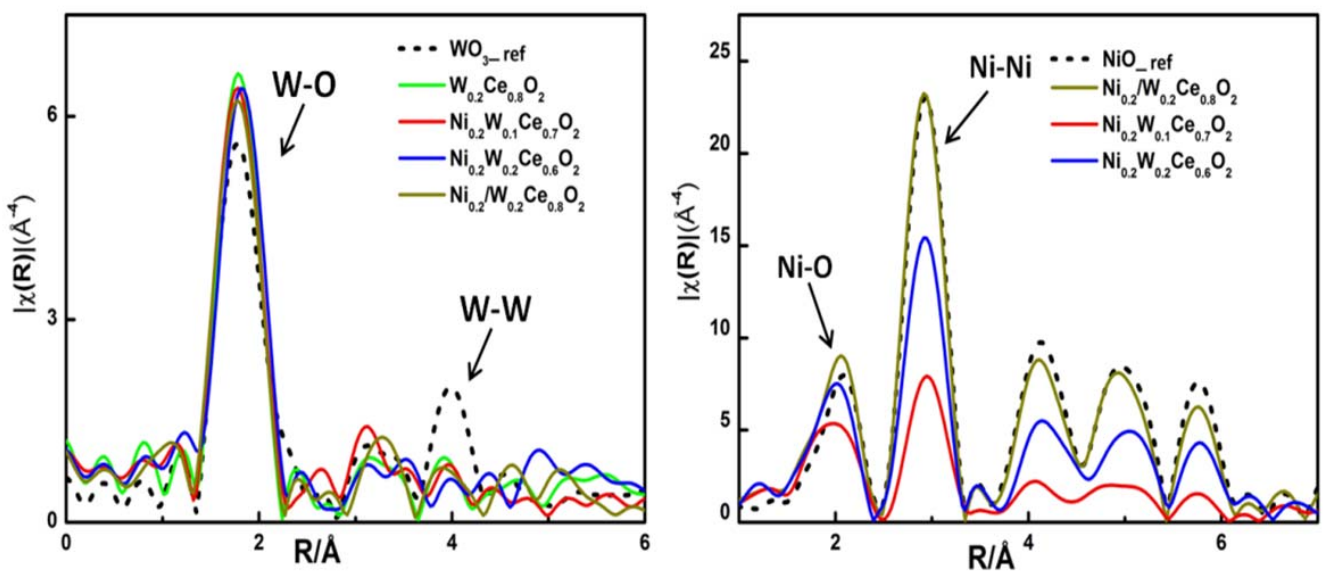

Fig 4 

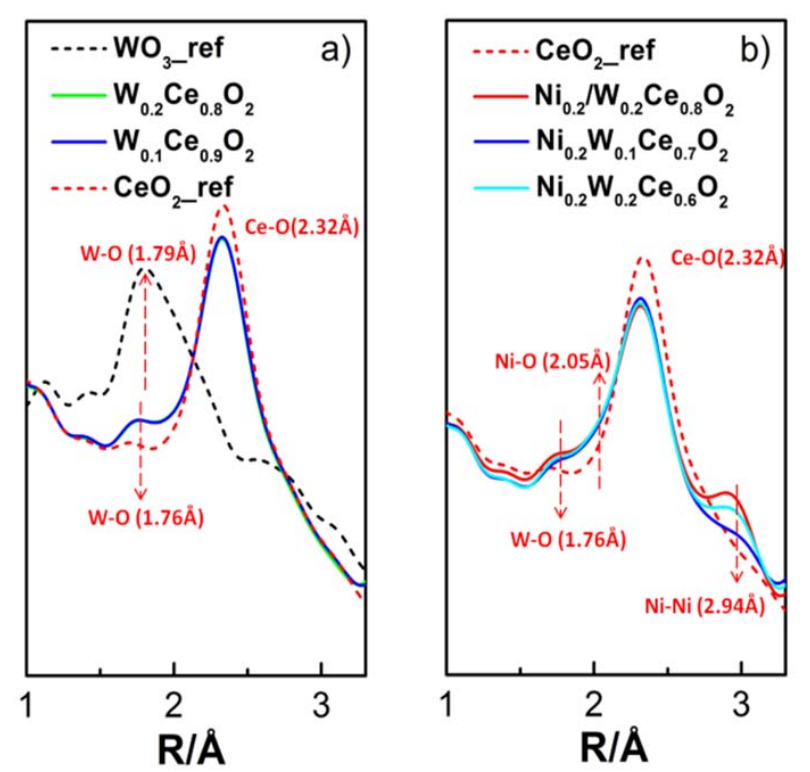

Fig 5 


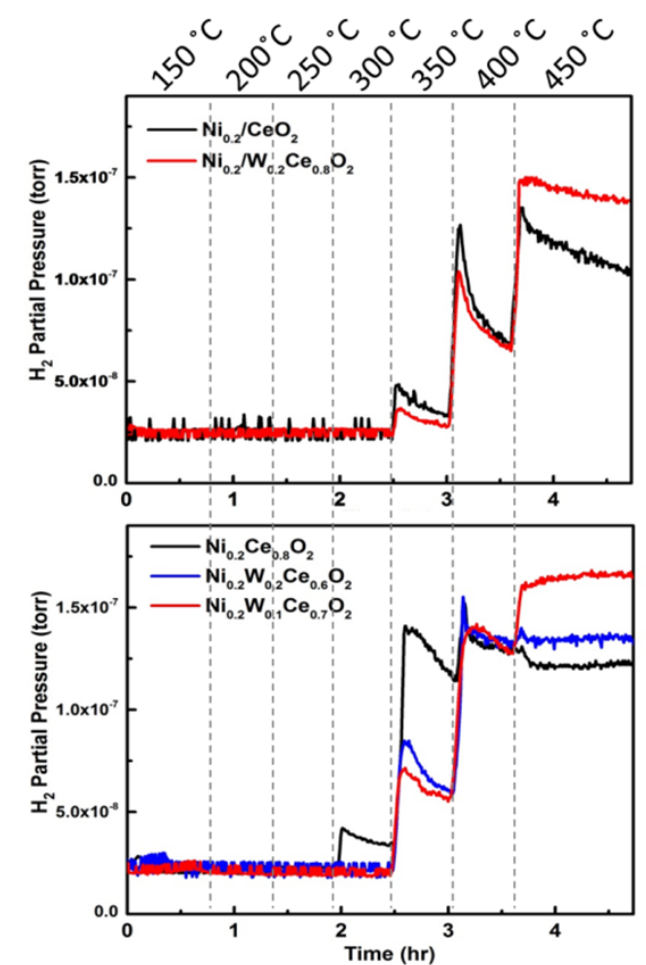

Fig 6 


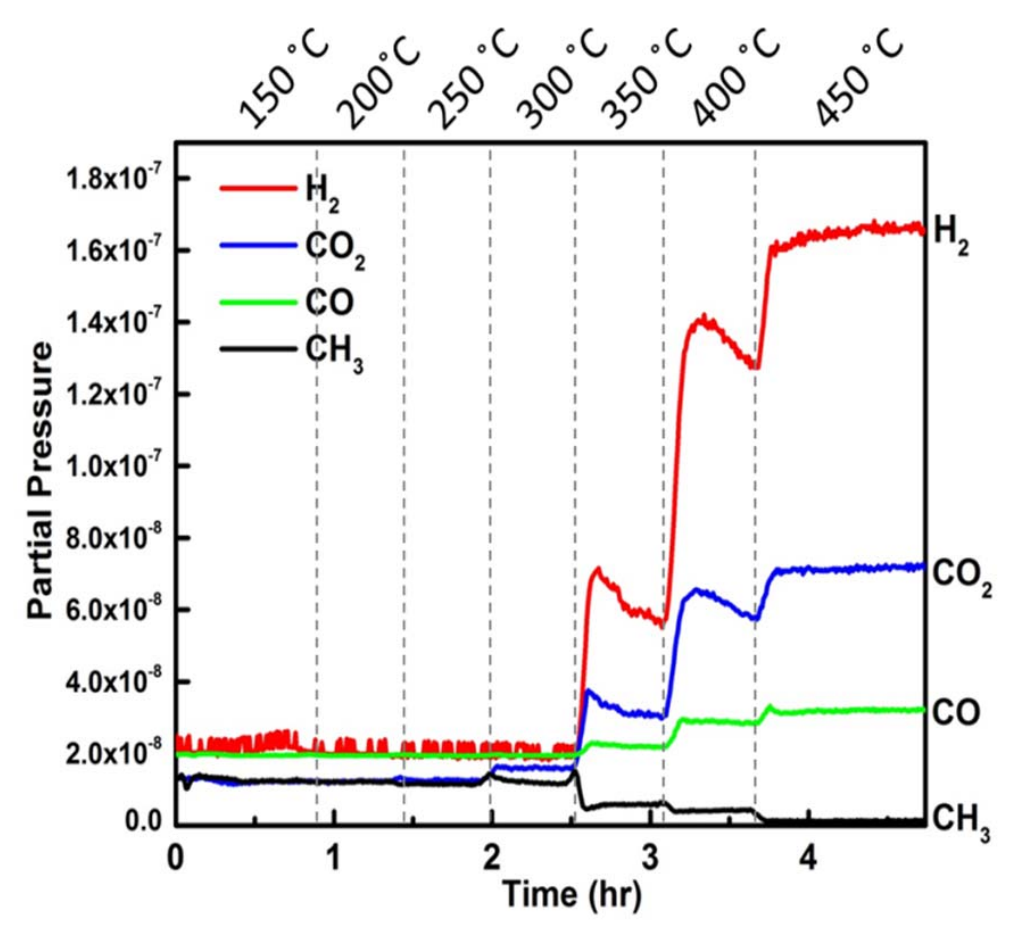

Fig 7 


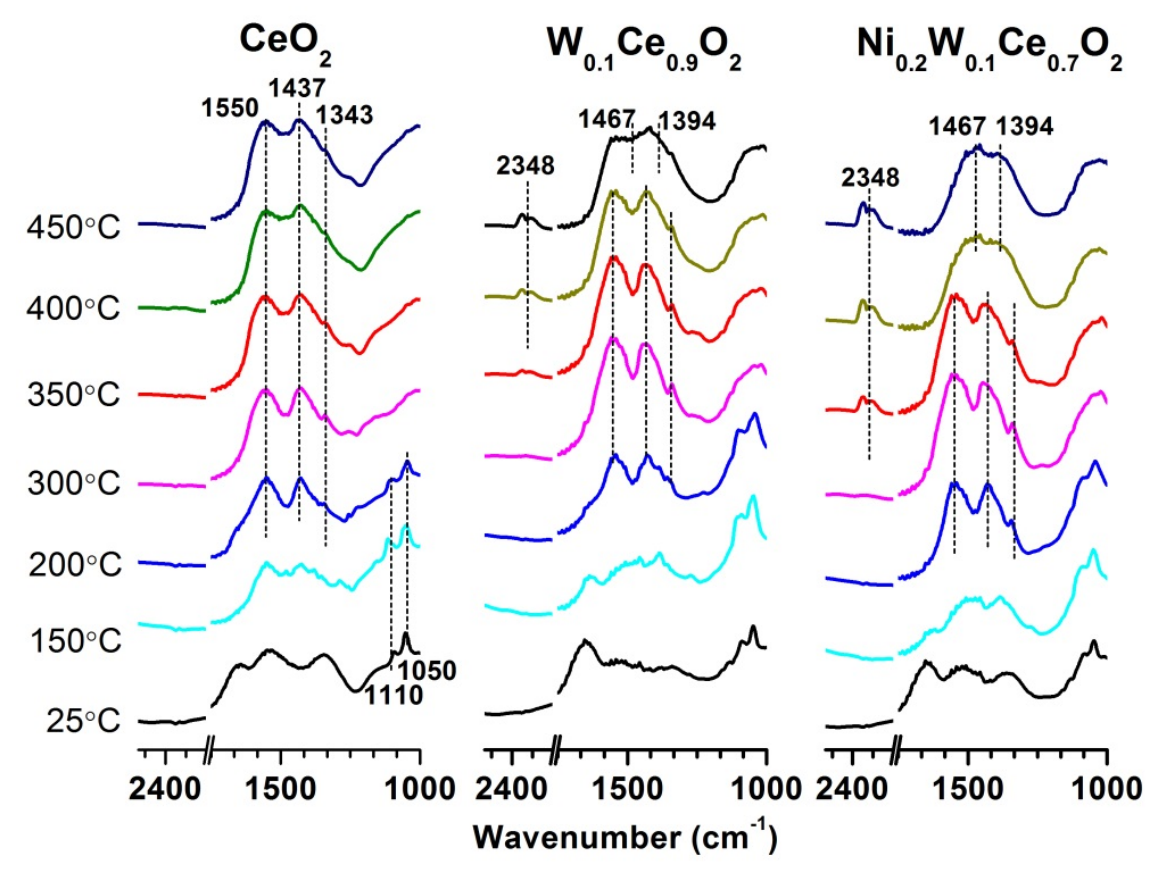

Fig 8 


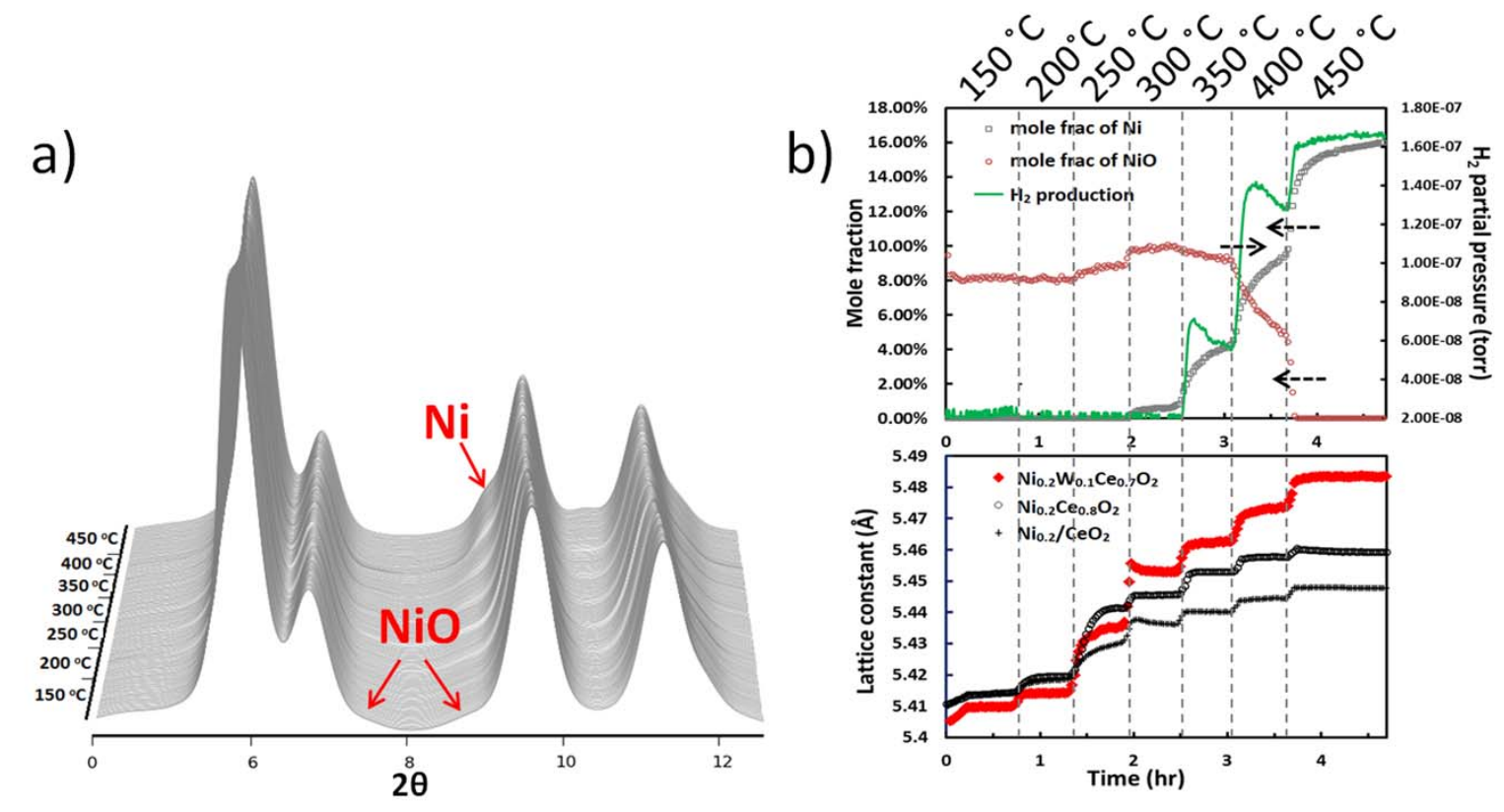

Fig 9 


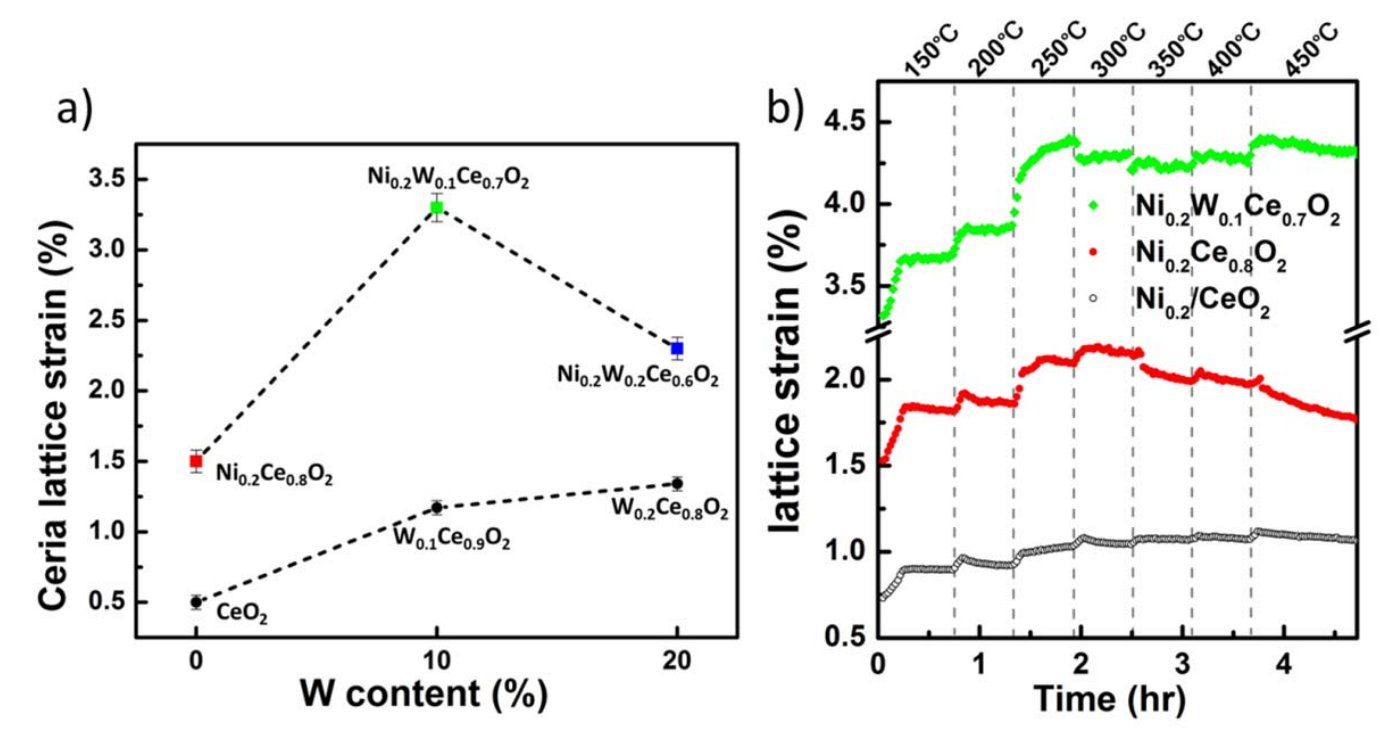

Fig 10 


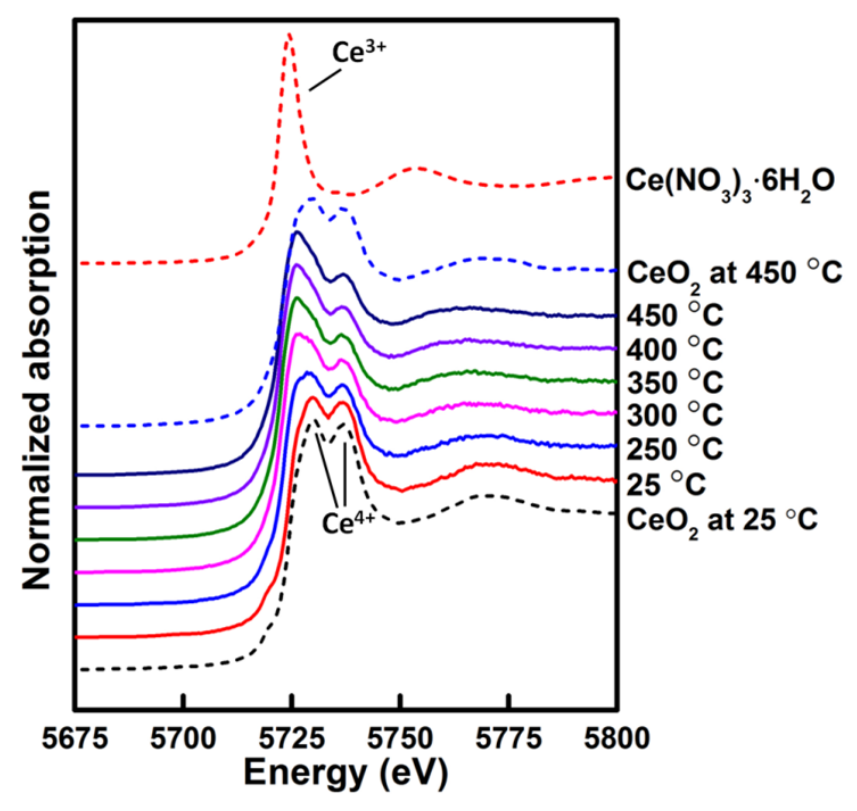

Fig 11 

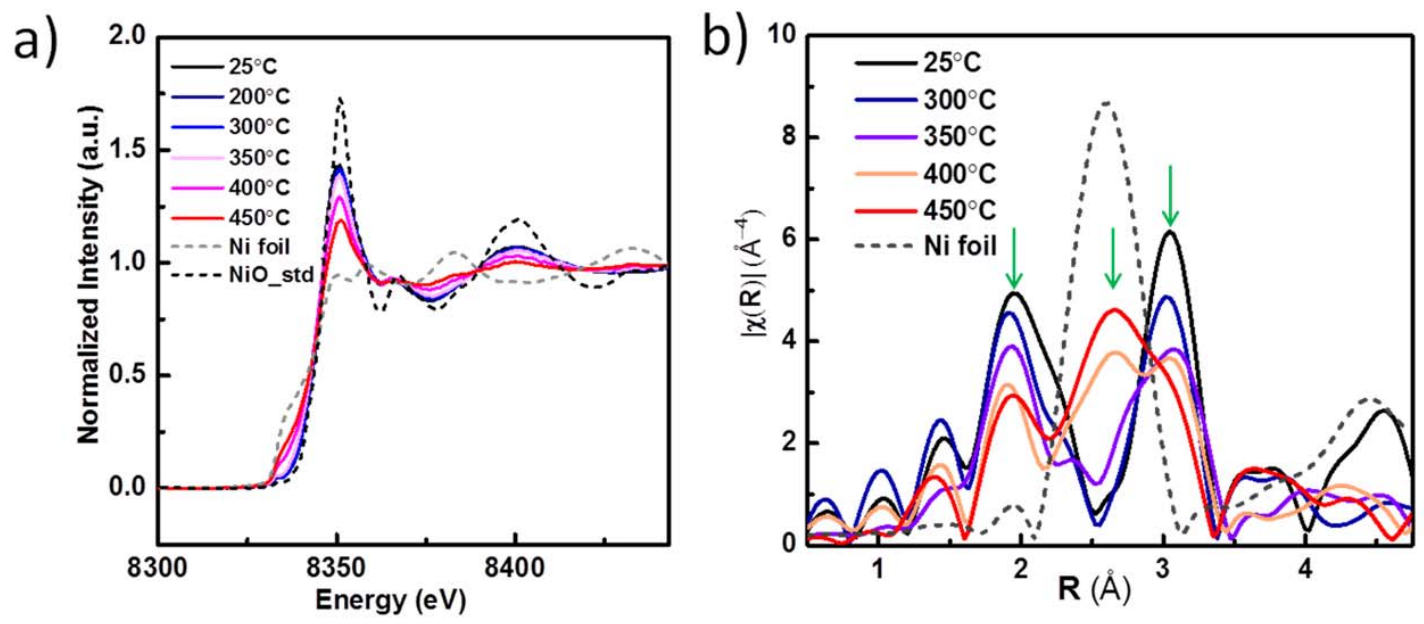

Fig 12 